\title{
Take a deep breath... The evolution of the respiratory system of symphytognathoid spiders (Araneae, Araneoidea)
}

\author{
Lara Lopardo $^{1}$ D $\cdot$ Peter Michalik ${ }^{1} \cdot$ Gustavo Hormiga $^{2}$
}

Received: 22 February 2021 / Accepted: 8 September 2021 / Published online: 10 November 2021

(c) The Author(s) 2021

\begin{abstract}
Spiders are unique in having a dual respiratory system with book lungs and tracheae, and most araneomorph spiders breathe simultaneously via book lungs and tracheae, or tracheae alone. The respiratory organs of spiders are diverse but relatively conserved within families. The small araneoid spiders of the symphytognathoid clade exhibit a remarkably high diversity of respiratory organs and arrangements, unparalleled by any other group of ecribellate orb weavers. In the present study, we explore and review the diversity of symphytognathoid respiratory organs. Using a phylogenetic comparative approach, we reconstruct the evolution of the respiratory system of symphytognathoids based on the most comprehensive phylogenetic frameworks to date. There are no less than 22 different respiratory system configurations in symphytognathoids. The phylogenetic reconstructions suggest that the anterior tracheal system evolved from fully developed book lungs and, conversely, reduced book lungs have originated independently at least twice from its homologous tracheal conformation. Our hypothesis suggests that structurally similar book lungs might have originated through different processes of tracheal transformation in different families. In symphytognathoids, the posterior tracheal system has either evolved into a highly branched and complex system or it is completely lost. No evident morphological or behavioral features satisfactorily explains the exceptional variation of the symphytognathoid respiratory organs.
\end{abstract}

Keywords Comparative morphology $\cdot$ Cladistics $\cdot$ Tracheal system $\cdot$ Miniaturization $\cdot$ Mysmenidae $\cdot$ Symphytognathidae $\cdot$ Anapidae $\cdot$ Micropholcommatinae $\cdot$ Theridiosomatidae $\cdot$ Synaphridae

\section{Introduction}

The study of the respiratory organs of Arachnida has a long trajectory, with the first anatomical account published more than two centuries ago (Meckel, 1809:109). The book lungs of Scorpiones were then referred to as "gills," and it was only some years later in 1828 that their pulmonary nature was recognized (see review in Purcell, 1909). Respiratory organs within Arachnida are diverse and include book lungs, tracheae, or can be completely absent (see, e.g., Levi, 1967; Dunlop, 2019; Küntzel et al., 2019). Book lungs seem to be structurally homologous within pulmonated Arachnida (Scholtz \& Kamenz, 2006), and their presence is a

Lara Lopardo

lara.lopardo@uni-greifswald.de

1 Zoologisches Museum, University of Greifswald, Loitzer Str. 26, 17489 Greifswald, Germany

2 Department of Biological Sciences, The George Washington University, 2029 G Street NW, Washington DC 20052, USA synapomorphy of Arachnopulmonata (Sharma et al., 2014; Scorpiones, Araneae, Pedipalpi, and most likely Schizomida). Recent genomic studies (Ontano et al., 2021) have enlarged the composition of Arachnopulmonata by supporting a sistergroup relationship between Scorpiones and Pseudoscorpiones (a lineage now known as Panscorpiones) in which case the absence of book lungs in pseudoscorpions is inferred to be secondary (that is, the book lungs are lost).

Although the morphology of book lungs is quite conservative across all pulmonate arachnids and these organs are considered as homologous, comprehensive comparative studies have found an interesting diversity of fine structures of the book lungs of Scorpiones, Amblypygi, Uropygi, and Araneae (Kamenz et al., 2005; Scholtz \& Kamenz, 2006; Kamenz \& Prendini, 2008; Küntzel et al., 2019). Early branching lineages of the order Araneae (spiders) possess the most ancestral condition of two pairs of book lungs on the second and third opisthosomal segments (see below). In addition, while the respiratory system within most arachnid orders remains constant, spiders are unique in that breathing 
in most of its distal lineages occurs simultaneously via book lungs and tracheae, or tracheae alone. Spider respiratory physiology has been studied for more than a century and is reviewed in Schmitz (2016).

The anterior respiratory system (ARS) of spiders is situated in the second opisthosomal segment (epigastric area, between the pedicel and the epigastric furrow) and consists of the anterior book lungs in most species. The book lung spiracles are openings usually connected with the epigastric furrow. Internally, each spiracle opens into an atrium, which in turn is connected to horizontally organized air pockets, the flat lamellae: each lamella is a leaf-like tracheal structure with very thin cuticle that allow the gas exchange to occur (see Ramírez, 2000, 2014). The posterior respiratory system (PRS) is located in the third opisthosomal segment (postepigastrium, between the epigastric furrow and the posterior spiracles) and bears book lungs or tracheae (see Foelix, 2011). The basic tracheal arrangement in most araneomorph ("true") spiders consists mostly of a single tracheal spiracle located near the spinnerets, and includes a short, flat atrium, and two pairs of tracheae (lateral and median). The tracheae are mostly contained but distributed freely within the opisthosoma. Tracheal arrangements in different spider families present different degrees of complexity, from short, simple abdominal tubes to highly branched tubes reaching the prosoma (e.g., Lamy, 1902; Purcell, 1909, 1910; Petrunkevitch, 1933; Marples, 1955; Forster, 1970; Blest, 1976; Millidge, 1986; Bromhall, 1987; Ramírez, 2000, 2014; Ramírez et al., 2021). Most posterior tracheae and most anterior tracheae/book lungs are interconnected by the transverse duct: a canal connecting the atria and tracheal trunks at their base (Lamy, 1902; Purcell, 1909, 1910; Ramírez, 2000). The transverse duct is lined with spicules that prevent it from collapsing (Ramírez, 2000, and references therein) and therefore is a relatively rigid duct. Not only the complexity, but also the diversity of posterior tracheal configurations in spiders is remarkable. The posterior respiratory system may consist of two lateral sac-like tracheae ("reduced book lungs") plus median apodemes (e.g., Filistatidae); two lateral and two median tracheae, plus a pair of intermediate sac-like tracheae (i.e., a pair of single leaves; e.g., in Austrochilidae); two lateral and two median tracheae leading to a single posterior spiracle (e.g., most Entelegynae); a widely variable configuration of tracheae and apodemes, but without median tracheae (Synspermiata sensu Michalik \& Ramírez, 2014); complete absence of posterior respiratory system (e.g., "Lost Tracheae Clade": a clade within Synspermiata: Diguetidae, Tetrablemmidae, Pacullidae, Pholcidae and Plectreuridae); and an extreme condition where both pairs of book lungs are missing and the first pair is replaced by tracheae (e.g., Caponiidae) (see Ramírez, 2000, 2014; Griswold et al., 2005; Wheeler et al., 2017; Ramírez et al., 2021).
As mentioned above, two pairs of book lungs are the plesiomorphic respiratory configuration for spiders, a condition also present in its early-branching lineages as well. It has long been established that the lateral tracheae are homologous to the posterior book lungs and the median tracheae derive from the third entapophyses and sometimes even retain a muscle insertion (Lamy, 1902; Purcell, 1909, 1910; Ramírez, 2000). Plausible evolutionary scenarios within Araneae suggest two, four, and up to six independent "simplification" events of the posterior respiratory organs where relatively simple tracheae-like structures are derived from book lungs (Forster, 1980; Huckstorf et al., 2015; Ramírez et al., 2021). Additionally, the evolution of complex tracheal systems (i.e., tracheae supplying the prosoma) or alternatively the loss of the posterior respiratory system seem to have occurred independently at least four times in each case from simple tracheal systems limited to the opisthosoma (Ramírez et al., 2021). It seems that after the (posterior) tracheal system evolved, it underwent active evolutionary changes, which explains - as is the case of arachnid orders - such enormous diversity of tracheal morphologies within spiders. Given the morphological complexity of the book lungs and the diversity of tracheal morphologies across Araneae (explained by multiple independent origins), an evolutionary scenario where book lungs are regained from a posterior tracheal system is considered unlikely (Huckstorf et al., 2015; Ramírez et al., 2021).

\section{The respiratory system of minute spiders - the case of symphytognathoids}

Symphytognathoid spiders are minute ecribellate orbweavers (Araneoidea) that build highly modified orb webs and exhibit a great diversity of respiratory structures and configurations. The name "symphytognathoids" was coined by Coddington (1986) for Forster's (1959: 270) concept of Symphytognathidae (sensu lato): "By "symphytognathoids" I mean the Mysmenidae, Anapidae, and Symphytognathidae; I do not mean to imply superfamily status for the group." (Coddington, 1986:7). Shortly thereafter symphytognathoids were expanded to include the family Theridiosomatidae (Coddington, 1990: 19) and its monophyly corroborated based on morphological characters and web-building behavioral data by Griswold et al. (1998) and Schütt (2003). Presently, Symphytognathoids include the families Anapidae, Mysmenidae, Symphytognathidae, Synaphridae, and Theridiosomatidae (Lopardo et al., 2011). Phylogenetic analyses based on Sanger sequencing data from a few nuclear and mitochondrial markers, the socalled "usual suspects", have consistently failed to corroborate the monophyly of symphytognathoids as originally proposed (Rix et al., 2008; Rix \& Harvey, 2010; Lopardo et al., 2011; Dimitrov et al., 2012, 2017; Hormiga \& Griswold, 2014; Wheeler et al., 2017; Fernández et al., 2018). Most of these 
analyses, however, do recover the monophyly of each individual symphytognathoid family with relatively good support. Sanger sequencing data have supported the monophyly of symphytognathoids only when combined with an extensive morphological and behavioral dataset (Lopardo et al., 2011). As it turns, the recalcitrant problem of resolving the interfamilial relationships of symphytognathoids resides at the crux of a much larger problem, the phylogenetic relationships of the 17 araneoid families. As a consequence, inquiry into the evolutionary chronicle of symphytognathoids is inextricably linked to the Araneoidea problem. Transcriptomic analyses of extensive taxonomic samples of araneoids and thousands of loci (Fernández et al., 2018; Kallal et al., 2021) have also refuted symphytognathoid monophyly with high nodal support values. Surprisingly, the most recent phylogenomic analyses (Kulkarni et al., 2020, 2021), using ultraconserved elements (UCEs) and up to 26 symphytognathoid representatives, suggest (and paradoxically also with high nodal support values) that when the sequence data are analyzed as nucleotides, rather than as amino acids, and when about a hundred or more loci are used, symphytognathoids are indeed monophyletic. We take this latter proposal as the best supported phylogenetic hypothesis of symphytognathoid relationships.

The earliest description of the respiratory system of a symphytognathoid was provided by Lamy (1902: fig. 47) for the theridiosomatid Theridiosoma gemmosum (Koch, 1877) (see hereafter supplementary material for authorship of taxa). This orb-weaving spider has the typical respiratory arrangement of most araneoids and entelegynes: anterior book lungs and a posterior tracheal system with two lateral and two median tracheae confined to the abdomen and opening into a small atrium leading to a single posterior spiracle. Subsequent studies, focusing mainly on Anapidae, have uncovered a remarkable diversity of respiratory arrangements in symphytognathoids (e.g., Forster, 1959, 1980; Gertsch, 1960; Levi, 1967; Levi \& Kirber, 1976), and concomitantly have proposed evolutionary hypotheses involving simplification of structures to explain such diversity of respiratory organs.

In the present study, we explore the evolution of the respiratory system of symphytognathoids by synthesizing all available information from the literature and combining it with our own data, mainly from the family Mysmenidae. The taxon sampling of our SEM analyses is based on Lopardo and Hormiga (2015), which provide the most comprehensive comparative morphological and behavioral dataset for symphytognathoids, together with the densest symphytognathoid taxon sampling to date. Additionally, we hypothesize evolutionary transformations to explain the diversity of respiratory structures based on comparative frameworks provided by the most extensive phylogenetic analyses of symphytognathoids to date. Finally, we provide an overview of factors that are plausibly affecting the evolutionary changes in the respiratory system of symphytognathoids.

\section{Material and methods}

Morphological methods follow Lopardo and Hormiga, (2015). All morphological data from the aforementioned comparative study was scrutinized for the examination of the respiratory systems. Additionally, we obtained new morphological data for the mysmenids Maymena ambita, M. mayana, M. rica, Trogloneta cantareira, T. granulum, Isela sp. (as Kilifina-MYSM-002-KENYA in Lopardo \& Hormiga, 2015), Mysmenopsis dipluramigo, Microdipoena guttata, and three undescribed Mysmena species from Madagascar and Argentina (Mysmena-MYSM-005-ARG, -015-MAD, and 028-MAD of Lopardo \& Hormiga, 2015); the anapid Tasmanapis strahan; the theridiosomatid Coddingtonia euryopoides and the synaphrid Cepheia longiseta. We further observed partially or completely the respiratory arrangements of five additional species: the mysmenids Mysmena woodwardi, an undescribed Mysmena from Mexico (Mysmena-MYSM-010-MEX), two mysmenines from Madagascar and Argentina (Mysmeninae-MYSM-008-ARG, and Mysmeninae-MYSM-009-MAD), and the anapid Sheranapis villarrica. The extent of observation of the respiratory arrangements depended on availability of specimens. See Appendix for a list of all examined material.

For observation of respiratory structures, we used the digestion method of Álvarez-Padilla and Hormiga (2008). Abdomens were bisected horizontally and digested with SIGMA Pancreatin P1750 enzyme complex, in a solution of sodium borate prepared using the concentrations described by Dingerkus and Uhler (1977), as modified by ÁlvarezPadilla and Hormiga (2008). Bisected abdomens were left in this solution at room temperature (i.e., $20-25^{\circ} \mathrm{C}$ ) overnight or for a few hours. After enzymatic digestion, abdomens were transferred to distilled water, and then to ethanol. For SEM study, the digested abdomens were dried using an Autosamdri-815 (Tousimis ${ }^{\circledR}$, Rockville, MD) critical-point drier using separate porous capsules, mounted on aluminum rivets with adhesive copper conductive tape, and then sputter-coated with gold-palladium using a Desk II LLC Cold Sputter Coater (Denton Vacuum, Moorestown, NJ, USA). Images were taken with a LEO 1430VP scanning microscope at the Department of Biological Sciences SEM facility (The George Washington University, GWU).

In addition, we performed an exhaustive taxonomic literature survey for all species currently described within the symphytognathoids (collected and generously accessible from the online World Spider Catalog; WSC, 2020) and scrutinized the available literature for descriptions or information related to respiratory system structures (see Table 1 and supplementary material). Schematic drawings representing all observed/reported respiratory arrangements, 


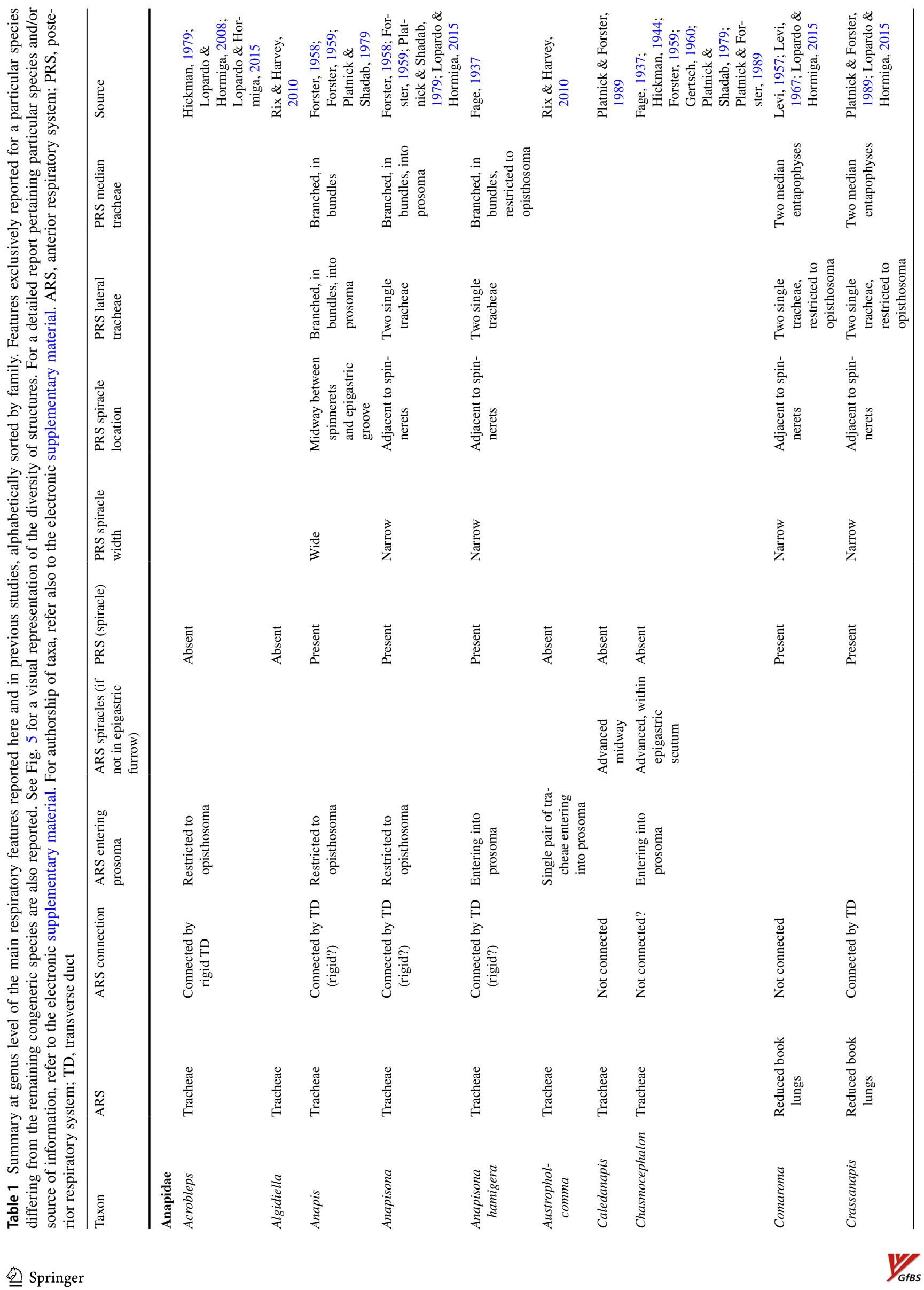




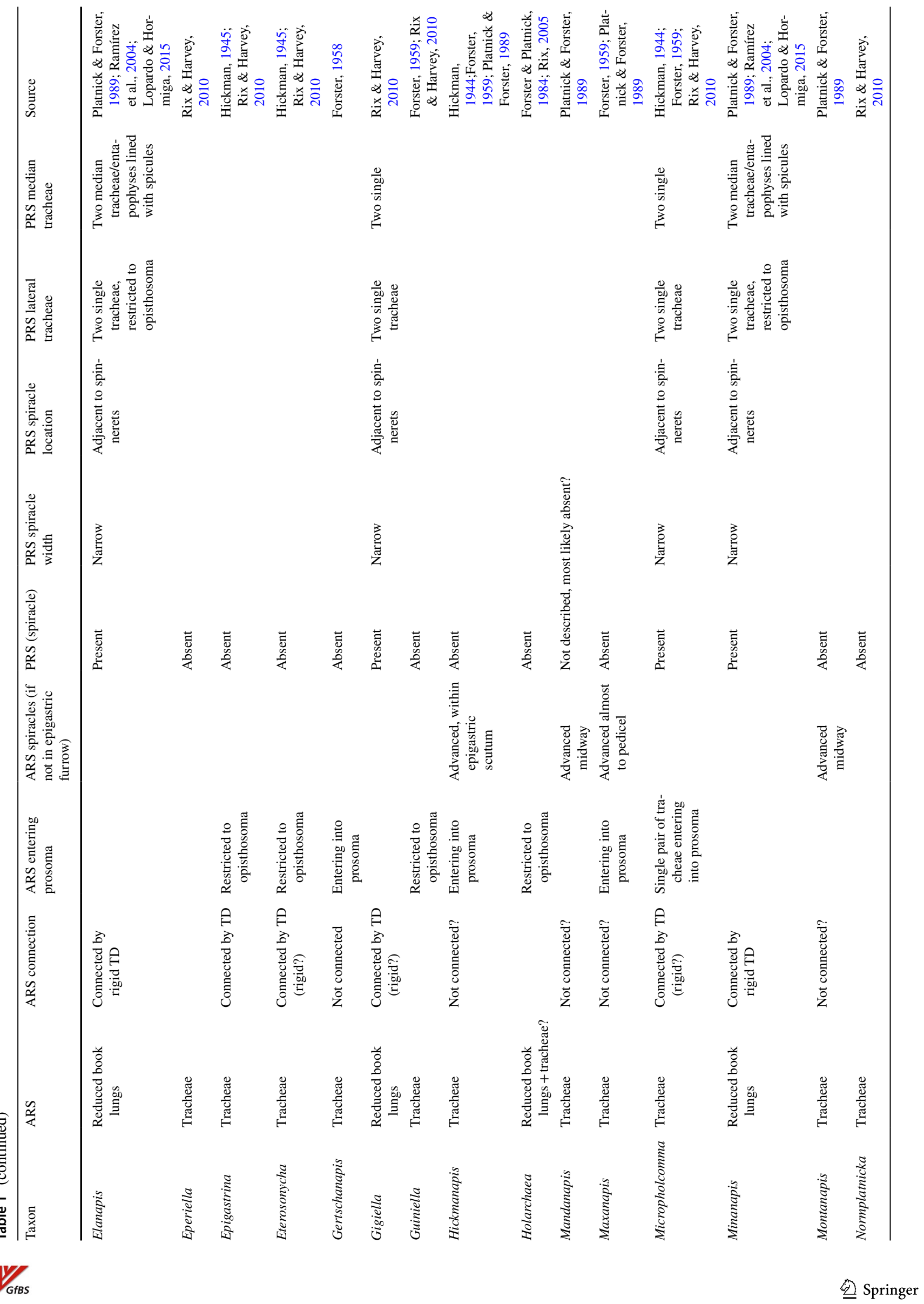




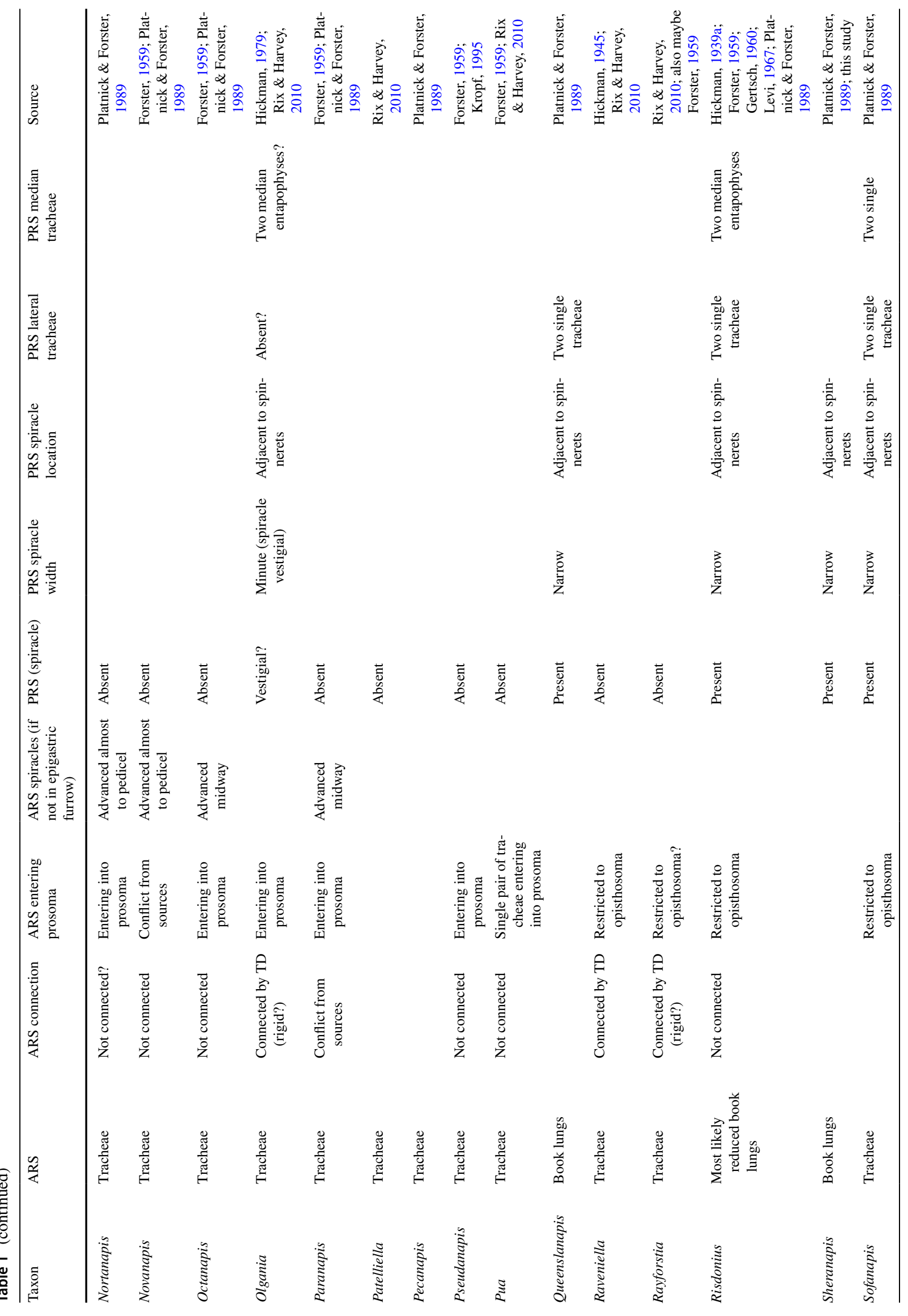




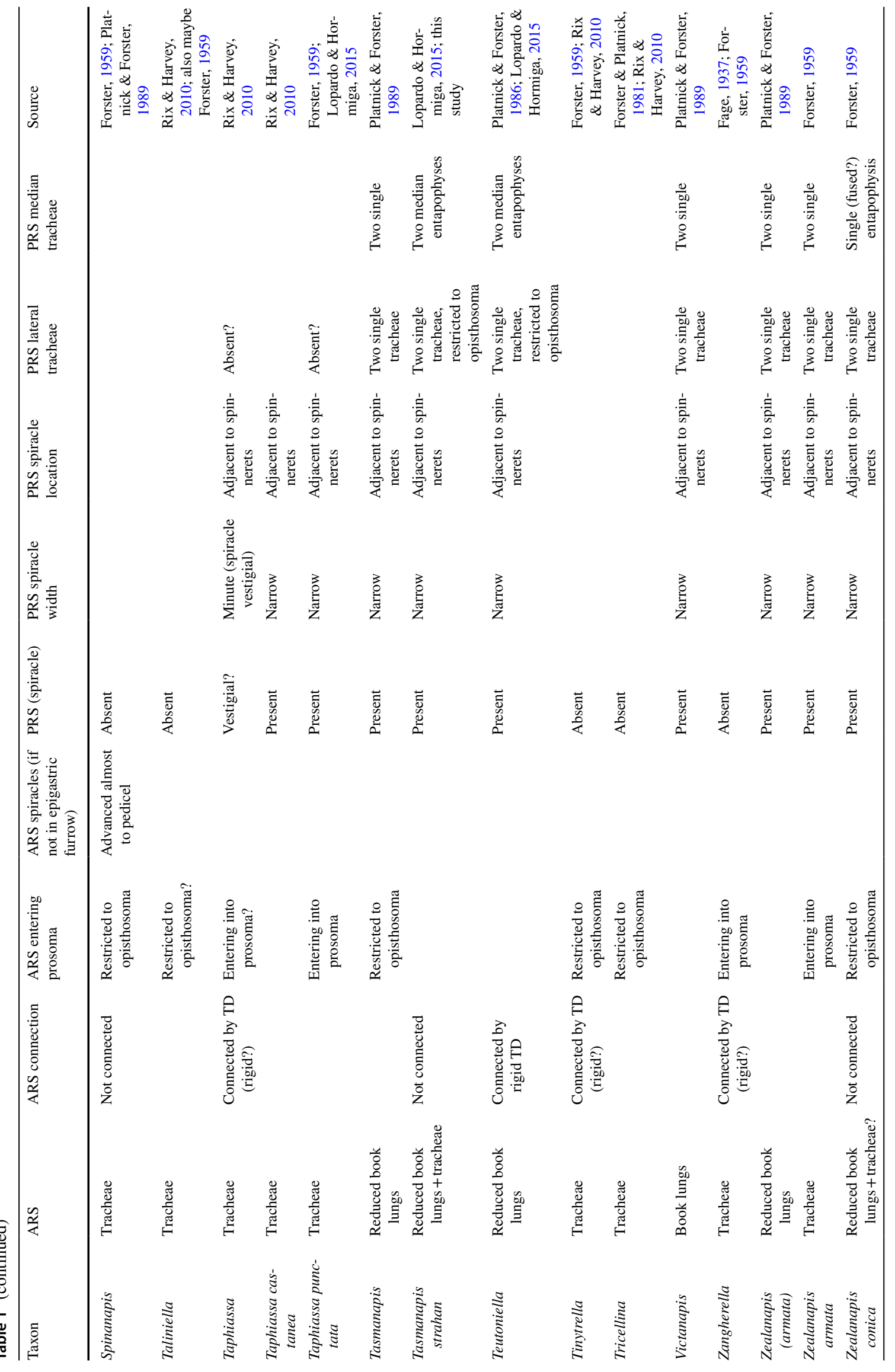




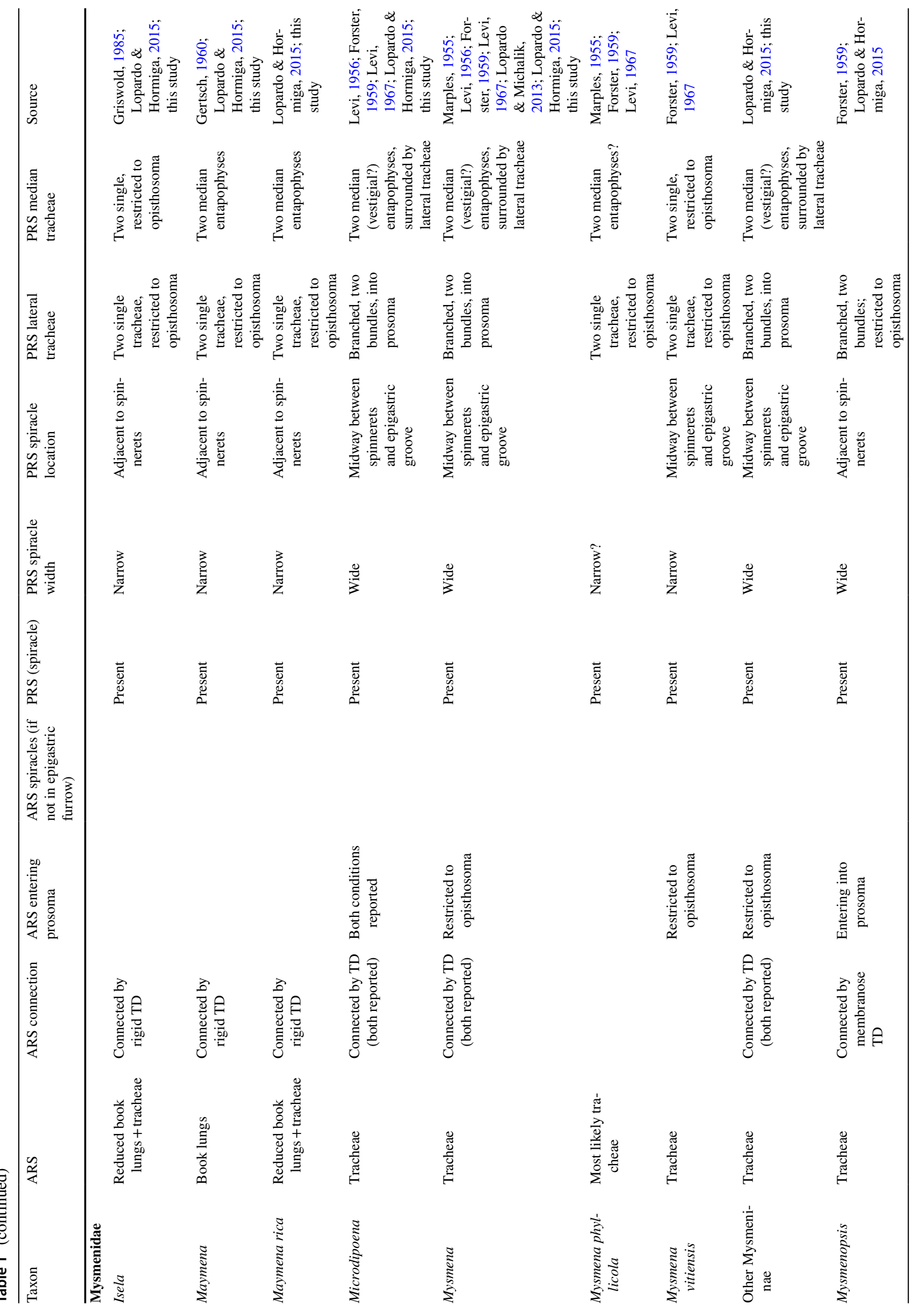




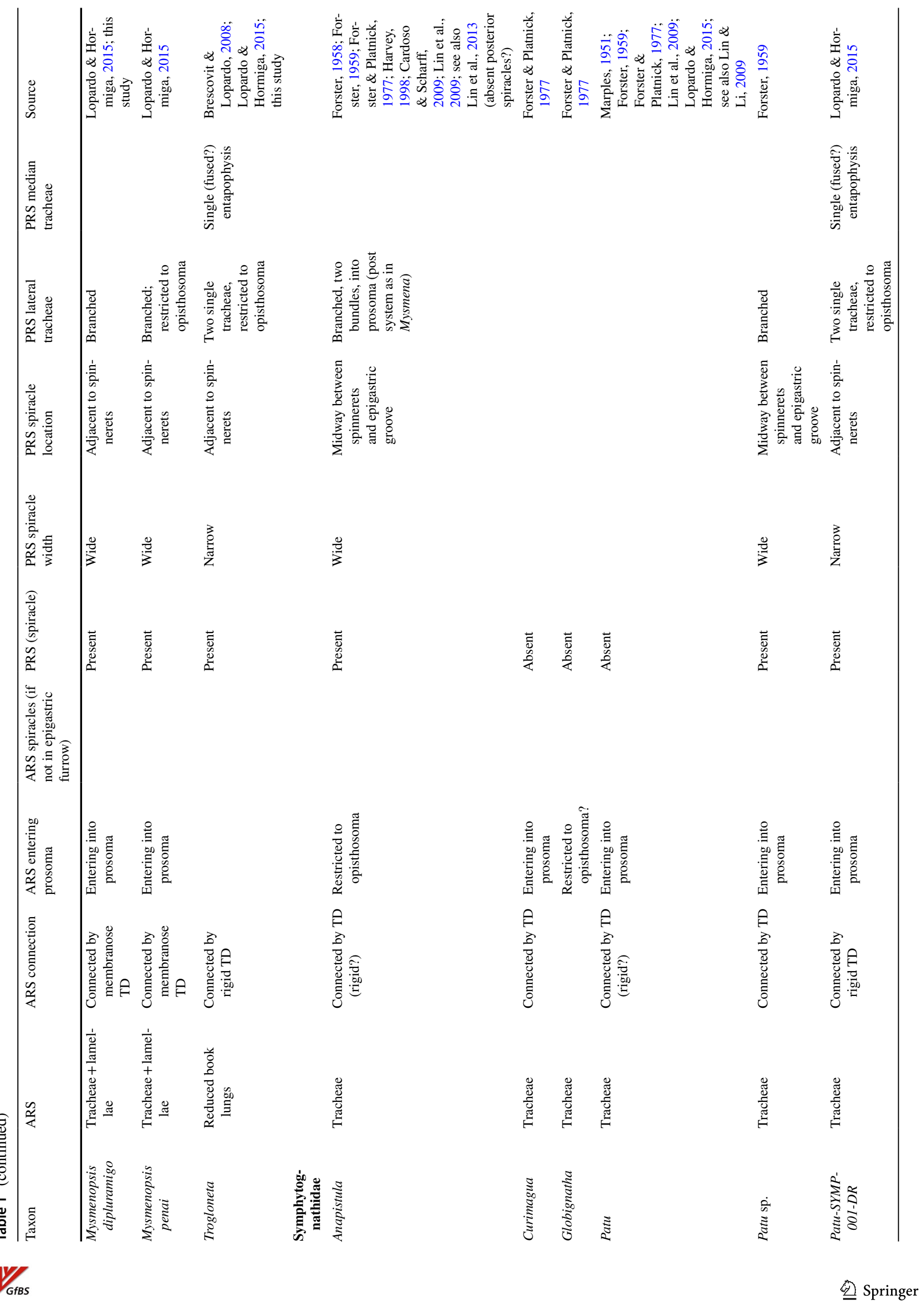




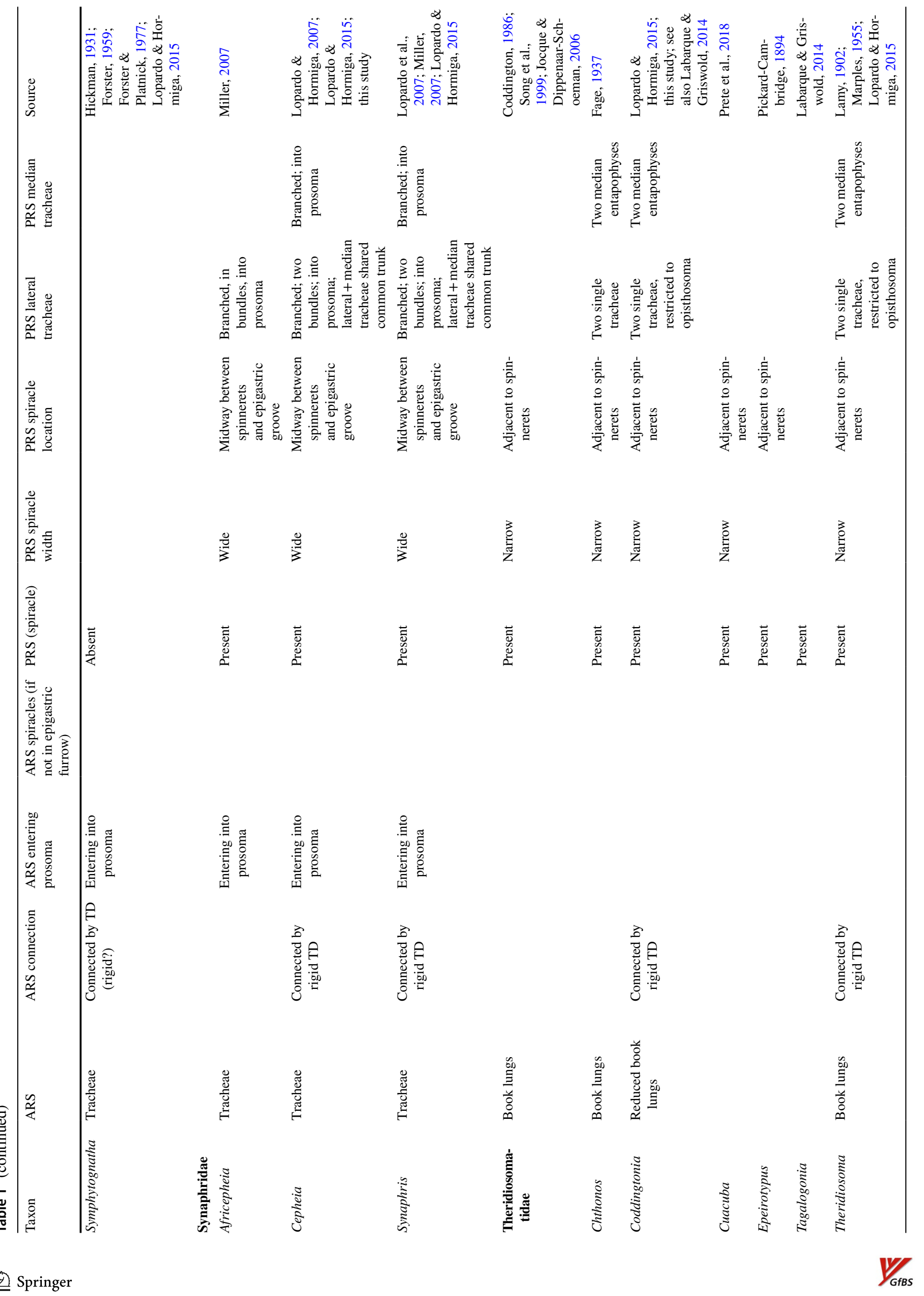


tree edition, and edition, assemblage and labeling were done using CorelDRAW Graphics Suite 2020.

The distinction between short median tracheae and relatively long third entapophyses lies in the lining of spicules preventing the walls of the (hollow) tracheae from collapsing, whereas the entapophyses are usually solid and lack spicules (Lamy, 1902; Purcell, 1909; Ramírez, 2000). No observation under light microscopy was performed in this study to discern both structures. However, as mentioned above, median tracheae can sometimes retain a muscle insertion; therefore, the comparatively very short median structures observed here (e.g., compare lateral and median structures in Figs. 1b, 3e, 4c against 2a) are assumed to have a negligible respiratory performance, and instead a more predominant muscle attachment function.

The reconstruction of the evolution of respiratory systems in symphytognathoids is based on the optimization of characters 21-33 of Lopardo and Hormiga (2015, their Appendix 2). Outgroup taxa are represented by species in the araneoid families Tetragnathidae, Linyphiidae, and Theridiidae. The parsimony optimizations were performed in TNT v1.1 (Goloboff et al., 2008) using the two alternative hypotheses of interfamilial relationships recovering Symphytognathoids as a monophyletic group (but see below for a discussion on the optimization under non-monophyletic hypotheses). The first hypothesis is the preferred optimal tree of Lopardo et al. (2011: fig. 12), and it is based on their total evidence analysis that combined morphological, behavioral and Sanger sequence data. The second hypothesis uses the interfamilial relationships of the UCE topology of Kulkarni et al. (2021: fig. 4b), which results from a dataset that included a combination of the taxon sample of UCEs recovered from the transcriptomic study of Fernández et al. (2018) and the UCEs of Kulkarni et al. (2020). This second topology is based on the same taxon sample as the first tree with the symphytognathoid intrafamilial relationships also taken from Lopardo et al. (2011: fig. 12). The independent regains of the anterior book lungs and the concomitant non-homology of such a complex trait was investigated under two alternative character codings. The first coding approach follows the original multistate character from Lopardo and Hormiga (2015; character 21): anterior respiratory system: (0) book lungs with more than 20 leaves, (1) book lungs with less than 15 leaves "reduced book lungs," (2) tracheae). In the second approach, we recoded the multistate character as two binary characters: anterior respiratory system: (0) book lungs, (1) tracheae; and book lung leaves: (0) with more than 20 leaves, (1) less than 15 leaves (species with anterior tracheae were scored as "unapplicable" for this second binary character). Character recoding was performed using the program Winclada (Nixon, 1999). For both phylogenetic frameworks, we additionally explored the optimization under asymmetric character state changes on the first binary recoded character (i.e., book lungs vs. tracheae), applying the parsimony approach performed by Miller et al. (2010; see references therein, see also Oakley \& Cunningham, 2002), in TNT using a Sankoff matrix under parsimony and searching for the minimum loss/gain ratio that produces homology of the book lungs and forces multiple independent origins of tracheae across the tree (i.e., transformation costs ranging from even (100/100) to asymmetric (100/1): ccode $(21$; cost $21=1>0100 \quad 0>1$ 100; to ccode $(21 ; \operatorname{cost} 21=1>01000>1$;;).

\section{Results and discussion}

\section{Comparative morphology of the respiratory system of symphytognathoid families (refer to Figs. 5-7, Table 1, and supplementary material)}

\section{Mysmenidae}

As currently circumscribed, Mysmenidae comprises 158 described species in 14 genera (World Spider Cata$\log$, WSC, 2020, see Lopardo \& Hormiga, 2015 for the removal of the genus Phricotelus from the family and its placement as Araneoidea incertae sedis). The respiratory system has been studied and described (or only reported) by a small number of arachnologists but for a relatively large number of species, encompassing six genera: Mysmena (Marples, 1955; Levi, 1956, 1967; Forster, 1959; Lopardo \& Michalik, 2013; Lopardo \& Hormiga, 2015), Microdipoena (Levi, 1956, 1967; Forster, 1959; Lopardo \& Hormiga, 2015), Mysmenopsis (Forster, 1959; Lopardo \& Hormiga, 2015), Maymena (Gertsch, 1960; Lopardo \& Hormiga, 2015), Isela (Griswold, 1985; Lopardo \& Hormiga, 2015), and Trogloneta (T. cantareira; Brescovit \& Lopardo, 2008; Lopardo \& Hormiga, 2015). There is a large diversity of respiratory arrangements within Mysmenidae (see Table 1 and supplementary material). Contrary to other symphytognathoid families (see below), and except for a few species, a different and peculiar arrangement can consistently be found on each particular genus or subfamily, which are described below. The ancestral mysmenid respiratory system based on the total evidence phylogenetic hypothesis of Lopardo et al. (2011) is as follows: anterior tracheal system extending into the prosoma and connected by a transverse duct; posterior tracheal system comprising a single narrow spiracle adjacent to the spinnerets and internally consisting of a small atrium, median entapophyses and lateral tracheae restricted to the opisthosoma, and arranged separately, most likely resulting in four trunks usually arising independently from the posterior spiracle, via a small atrium (Figs. 5 and 6). No extant mysmenid species, however, is known to have this hypothetical 
ancestral tracheal system. The mysmenid ancestral reconstruction based on the phylogenetic hypothesis of Kulkarni et al. (2021) renders a similar anterior respiratory arrangement; but due to the placement of Synaphridae as sister to Mysmenidae, the reconstruction of the posterior respiratory system is rendered ambiguous (median tracheae as third entapophyses, but either a simple or a complex lateral tracheal system) (not shown, refer to Figs. 5 and 7). The respiratory system for Brasilionata, Chanea, Gaoligonga, Mosu, Mysmeniola, Phricotelus, Simaoa, and Yamaneta remains unknown.
Maymena The anterior respiratory system of Maymena has been studied in Maymena mayana by Gertsch (1960), and its respiratory arrangement ("Book lungs present and tracheal tubes arising from spiracle located immediately in front of spinnerets"; Gertsch, 1960:31) was assumed to be similar in the additional Maymena species described in that study (i.e., M. chica, M. misteca, M. calcarata, and M. ambita). The respiratory system of Maymena was also briefly reported in Lopardo and Hormiga (2015:778). Anteriorly, M. mayana and M. ambita possess book lungs consisting of about 20 leaves and connected by a rigid trans-
Fig. 1 The respiratory system of Mysmenidae - the genera Maymena and Trogloneta. Dorsal view. a $M$. ambita, ARS. b $M$. ambita, PRS with two median entapophyses and two single lateral tracheae. c $M$. mayana, ARS. d M. rica, ARS with reduced book lungs and tracheal tubes. e T. cantareira, overview of ARS and PRS. f $T$. cantareira, PRS with a single median entapophysis and two single lateral tracheae. $\mathrm{g} T$. granulum, ARS with reduced book lungs. Abbreviations: BL, book lung; $\mathrm{mE}$, median entapophysis; plT, posterior lateral trachea; rBL, reduced book lung; $\mathrm{Sp}$, spermatheca; TD, transverse duct; $\mathrm{Tt}$, tracheal tube
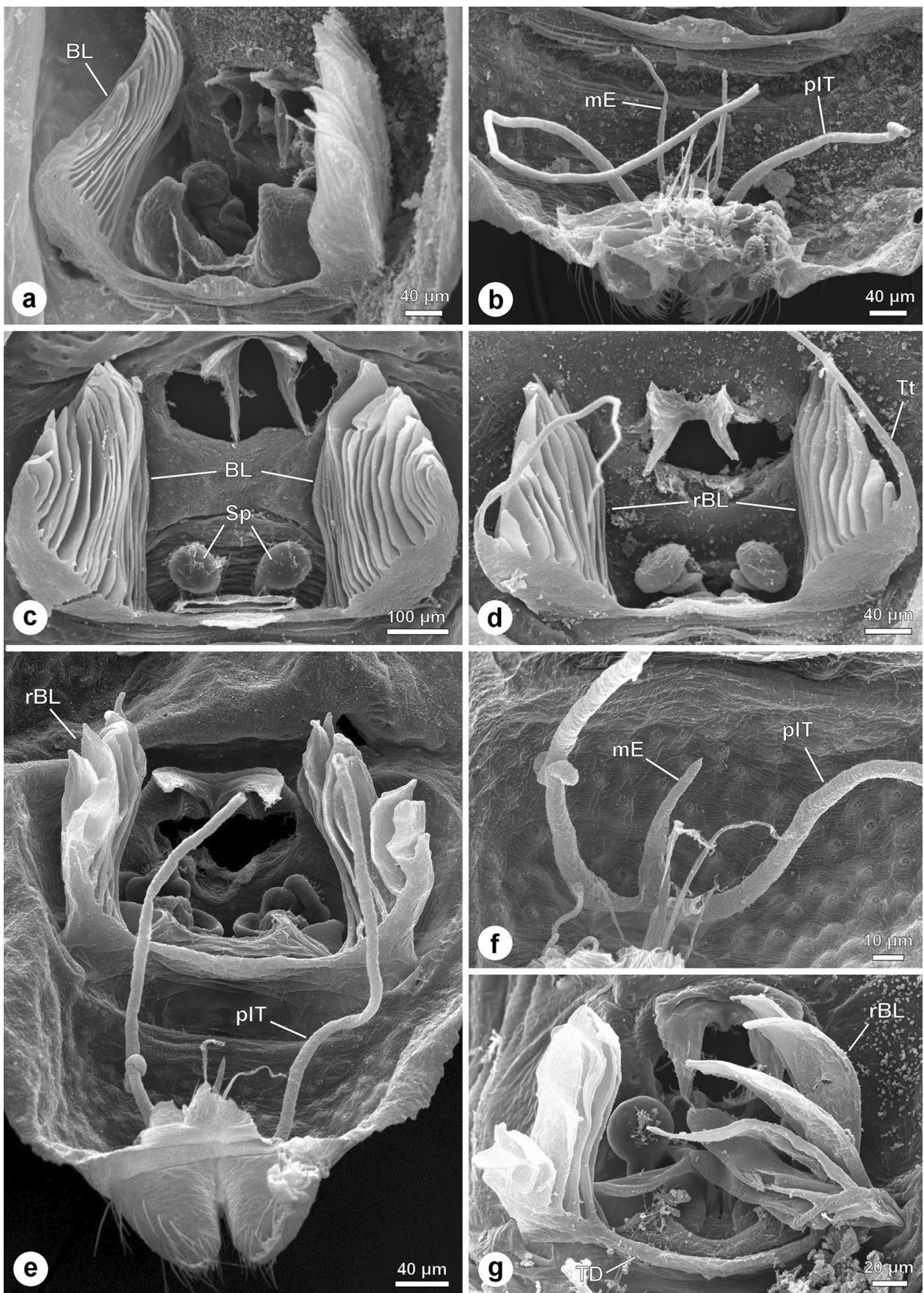
Fig. 2 The respiratory system of Mysmenidae - the genera Isela and Mysmenopsis. Dorsal view. a Isela sp., overview of ARS and PRS. b Isela sp., detail of left reduced book lungs showing the tracheal tubes arising from the most lateral and dorsal leaf. c Isela sp., detail of PRS showing the lack of median entapophyses. d-f Mysmenopsis dipluramigo. d Overview. e Detail of left anterior tracheae showing a book lung leaf arising ventrally. $\mathbf{f}$ Detail of PRS consisting of numerous tracheae. Abbreviations: BLl, book lung leaf; plT, posterior lateral trachea; pmT, posterior median trachea; rBL, reduced book lung; Sp, spermatheca; Tt, tracheal tube
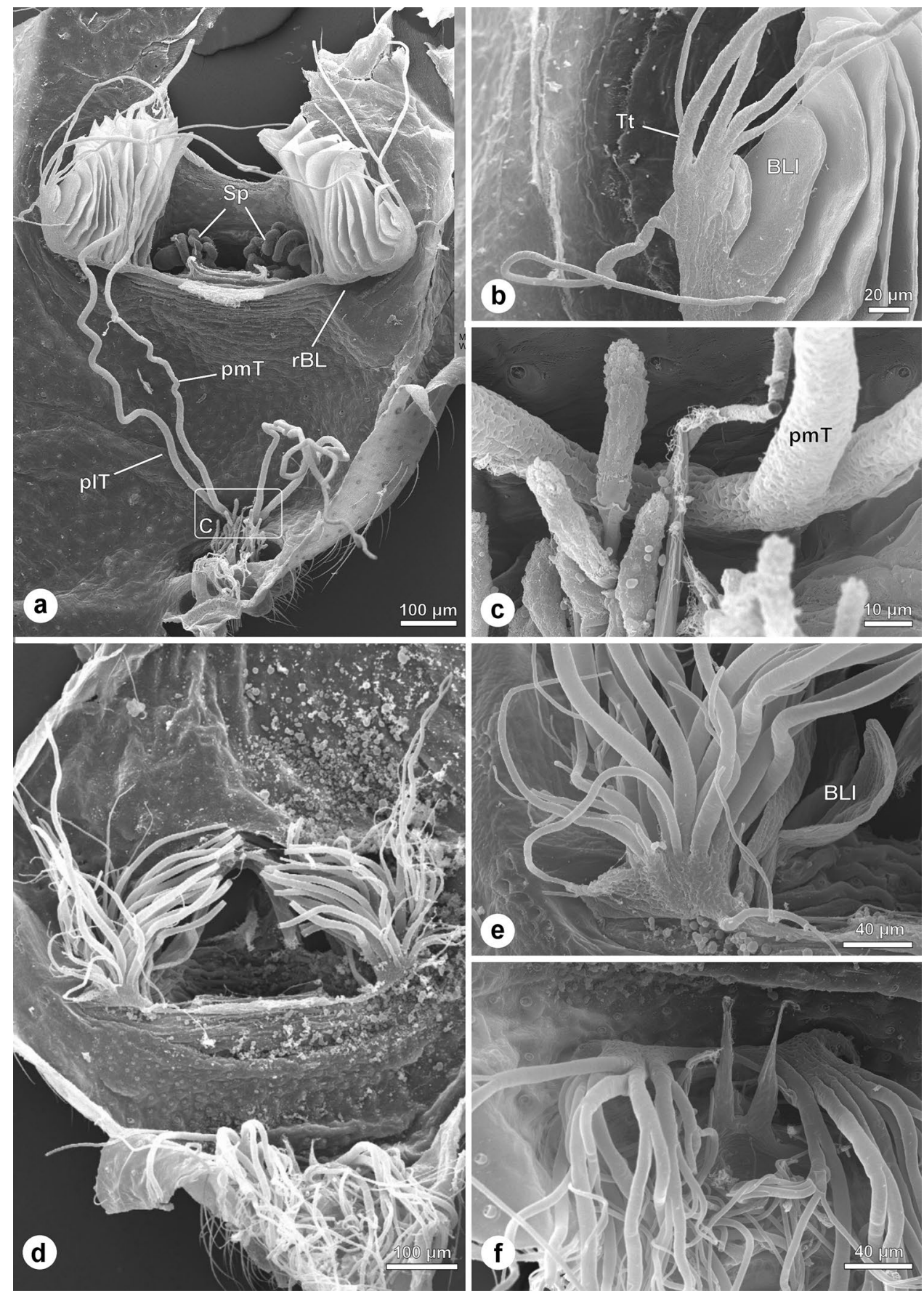

verse duct, in M. rica the book lungs are reduced (Fig. 1a, c, d). In addition, one tracheal tube arises from the reduced book lungs in M. rica (Fig. 1d; see discussion below). Posteriorly, all Maymena species studied have two long single lateral tracheal tubes (seemingly confined to the opisthosoma) and two short (seemingly) median entapophyses arising from a small atrium connected to a narrow posterior single spiracle (Fig. 1b), an arrangement identical to what can be regarded as the ancestral reconstruction of the mysmenid posterior respiratory system (Fig. 5). Concurrently, although characteristic of Maymena within Mysmenidae, the same respiratory arrangement of Maymena is also present in theridiosomatids as well as other members of Araneoidea (e.g., Steatoda), suggesting that this arrangement may have evolved independently within the family.

Trogloneta The respiratory system of Trogloneta has been described in detail for Trogloneta cantareira (Brescovit \& Lopardo, 2008) and also reported in Lopardo and Hormiga (2015:779). Anteriorly, two reduced book lungs with seven 
Fig. 3 The respiratory system of Mysmenidae - the subfamily Mysmeninae. a Microdipoena guttata, ventral view of opisthosoma showing the advanced and wide posterior spiracle with its two distinct openings (arrows). b Microdipoena guttata, dorsal view of ARS and PRS, which consist of numerous tracheae and especially the posterior tracheal tubes extending into the pedicel. c Mysmena-MYSM-015-MAD, dorsolateral view of ARS and PRS. d Mysmena-MYSM028-MAD, anterior view of the opisthosoma showing tracheal tubes extending into the pedicel. e Mysmena-MYSM-010-MEX, detail of PRS in dorsal view showing the small median entapophyses. Abbreviations: $\mathrm{aTt}$, anterior tracheal tubes; GO, genital opening; $\mathrm{mE}$, median entapophysis; pTt, posterior tracheal tubes; Sp, spermatheca; Spi, spiracle; TD, transverse duct; Tt, tracheal tube
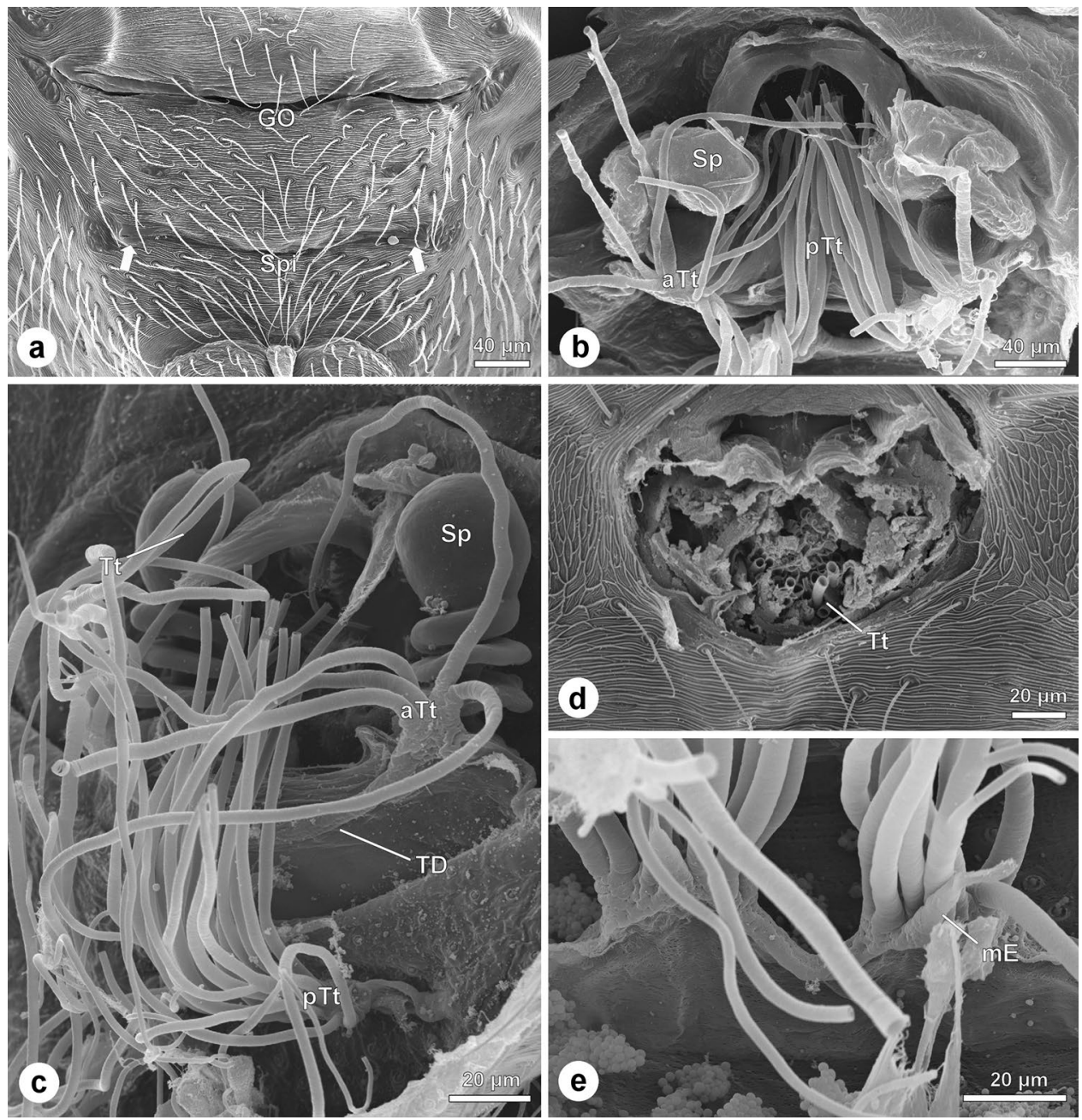

leaves each, connected by a rigid intertracheal transverse duct (Fig. 1e, g). Posteriorly, a tracheal system with one narrow spiracular opening located adjacent to the spinnerets, small atrium connected to two unbranched single lateral tracheae confined to the abdomen and one single unbranched (i.e., fused) seemingly median entapophysis. This distinct respiratory arrangement is also found in $T$. granulum (Fig. 1e, f), and it may be widespread within the genus.

Mysmenopsinae Each of the genera comprising the kleptoparasitic subfamily Mysmenopsinae is characterized by a different respiratory arrangement. The respiratory system of Isela was first described in detail by Griswold (1985) for $I$. okuncana. Posteriorly, one narrow spiracle located adjacent to the spinnerets, atrium connected to four long unbranching tracheal tubes (corresponding to a pair of single median tubes and a pair of single lateral tubes) confined to the abdomen. Anteriorly, the respiratory arrangement was described as "... atria giving rise to 13-14 short trachea-like lamellae..." (Griswold, 1985:208) also restricted to the abdomen. The respiratory system of another Isela representative was examined (Isela sp. - "Kilifina-MYSM-002-KENYA"; Lopardo \& Hormiga, 2015:780). Posteriorly, it is identical to the respiratory system described for I. okuncana (Fig. 2a, c); anteriorly, it has reduced book lungs of about 14-15 leaves, but it also has a cluster of about six tracheae arising dorsally from the most dorsal leaf of the lungs (Fig. 2a, b; see discussion below). This could have been the confusing mixed condition observed in I. okuncana under light microscopy. The anterior system of Isela $\mathrm{sp}$. is connected by a rigid intertracheal transverse duct, as it is presumably also in $I$. okuncana.

The respiratory system of Mysmenopsis was first reported for M. palpalis by Forster (1959), who discussed the details, diversity, and evolution of the respiratory system in many genera representing different families within symphytognathoids. Remarkably, the anterior system of this species consists of tracheae (not book lungs). The anterior tracheae extend to both prosoma and opisthosoma. Posteriorly, one wide spiracle (reported by Forster as two close spiracles) located adjacent to the spinnerets leads to two long tracheal tubes (most likely the lateral pair). 
The respiratory system of Mysmenopsis was described in Lopardo and Hormiga (2015:781, based on M. dipluramigo and $M$. penai): anterior tracheal system composed of several tracheoles extending to the abdomen as well as the prosoma, connected by a membranous intertracheal transverse duct (Fig. 2d). In addition to sharing the same anterior tracheal arrangement, all Mysmenopsis species have a wide posterior spiracle adjacent to the spinnerets. However, the posterior tracheal system of the two species examined in Lopardo and Hormiga (2015) differs from the one described by Forster (1959) in that it consists of two bundles of lateral branching tracheae arising from the atrium at each end of the posterior spiracle, seemingly restricted to the abdomen (Fig. 2d, f). The posterior median structures are presumed absent, or are alternatively functional tracheae intercalated with and identical to the lateral tracheal bundles.

Mysmeninae Each of the four characteristic respiratory arrangements mentioned above are typical of four different but closely related genera (Maymena, Trogloneta, Isela, and Mysmenopsis). The subfamily Mysmeninae, comprising the remaining investigated mysmenid genera (i.e., Microdipoena and Mysmena, and the several undescribed taxa examined herein and in Lopardo and Hormiga (2015); see Table 1 and supplementary material), have a remarkably different, although quite conserved, fifth type of respiratory arrangement, which is typical and unique for this subfamily (but see below). This respiratory system has been previously described (Marples, 1955; Levi, 1956, 1967; Forster, 1959), although these descriptions were understandably superficial in the absence of SEM examination (but see a detailed description of the respiratory system of Mysmena leichhardti in Lopardo and Michalik (2013) and of Mysmeninae in Lopardo and Hormiga (2015:783)). Anteriorly, several tracheal tubes seemingly restricted to the abdomen arise on each atrium, which are connected by a rigid intertracheal transverse duct (Fig. 3c). The posterior tracheal system opens through a wide and advanced tracheal spiracle located halfway between the spinnerets and the epigastric furrow. The shape of this wide spiracle is similar to that described for synaphrids (Lopardo \& Hormiga, 2007; Lopardo et al., 2007; see discussion below), consisting of two distant openings connected by a thin furrow (Fig. 3a). The thin furrow is almost imperceptible under light microscopy, and therefore it has been described as two separate spiracles in previous mysmenid studies. Internally, mysmenines have a common $\mathrm{M}$-shaped atrium, where two bundles of branching lateral tracheae arise on each side, most of them extending into the prosoma (Fig. 3b-d). Two-minute seemingly median entapophyses, each arising from the two most anterior locations of the M-shaped atrium, are each surrounded by a bundle of lateral tracheae (Fig. 3e). These apodemes are only visible by SEM and had been consequently overlooked in the original descriptions. Given that so far all examined Mysmeninae species seem to have this remarkable tracheal system (but see below), it seems reasonable to predict that this tracheal pattern is widespread in this subfamily.

The anterior respiratory system of Microdipoena guttata was described by Levi (1956; also 1967) as being an intermediate stage between tracheae and book lungs: “... structures between the seminal receptacles and the body wall which may be remains of book lungs but do not seem to be trachea" (Levi, 1956:3). The internal respiratory system of M. guttata (examined here and in Lopardo \& Hormiga, 2015), consists of a posterior system as described above (and also identical to that reported by Levi, 1956:3 “...trachea extending from the spiracles between spinnerets and genital groove, but these are bunched for a shorter distance and seem connected at their base"). Anteriorly, nevertheless, the extremely large, membranous and convoluted copulatory ducts of this species (also common within Mysmeninae) might have been misinterpreted as the "intermediate" structures (see e.g., Fig. 3b).

Two Mysmena species have each been reported as having a unique respiratory arrangement. Mysmena phyllicola has been described to have anterior book lungs of about five elongate lamellae (Marples, 1955), which was considered similar to the "intermediate stage" reported for Microdipoena guttata (see above; Forster, 1959), and a posterior respiratory system consisting of one single relatively advanced tracheal spiracle (located halfway between the spinnerets and the epigastric furrow) connected to four tracheal tubes restricted to the abdomen. Mysmena vitiensis, on the other hand, has two anterior unconnected tracheae, and one single and advanced posterior spiracle also connected to four tracheal tubes restricted to the abdomen (Forster, 1959). The holotype and only specimen of $M$. vitiensis was not available for study. The type material and only specimens of M. phyllicola were examined here, but no detailed observation was possible. Given the limited observations of the respiratory system of these two species and the peculiarity of their arrangements, more specimens are required to confirm the available data. Finally, we expect that the closely related genera Brasilionata and Mysmeniola as well as the three-dimensional spherical web builder genera Simaoa and Gaoligonga might also have a respiratory arrangement similar to those described here.

\section{Anapidae}

Anapidae is the largest symphytognathoid family, comprising 233 described species in 58 genera and including the subfamily Micropholcommatinae (World Spider Catalog, 
WSC, 2020). The respiratory system of Anapidae has been studied and partially or completely reported for quite a number of species belonging to 49 out of the 58 current genera (Hickman, 1939a, 1944, 1945, 1979; Fage, 1937; Forster, 1958, 1959; Gertsch, 1960; Levi, 1957, 1967; Platnick \& Shadab, 1979; Forster \& Platnick, 1981, 1984; Platnick \& Forster, 1986, 1989; Kropf, 1995; Ramírez et al., 2004; Rix, 2005; Lopardo \& Hormiga, 2008, 2015; Rix \& Harvey, 2010). Our findings and the published data suggest at least 14 different respiratory arrangements (Fig. 5, Table 1 and supplementary material), varying from anterior reduced book lungs and posterior simple or absent tracheae, to anterior tracheae and complex, simple, or even absent posterior tracheal system. The anterior tracheae/book lungs can be connected by a transverse duct or not connected, the tracheae extending into the prosoma or limited to the abdomen, and/or with spiracles connected to the epigastric groove or advanced and located near the pedicel. The respiratory system remains unknown for Borneanapis, Conculus, Crozetulus, Dippenaaria, Enielkenie, Forsteriola, Gaiziapis, Metanapis, and Sinanapis. Although it is out of our scope to perform a detailed review on the evolution of anapid respiratory system (a comprehensive phylogeny of the Anapidae that will allow for a more accurate account of their evolution is currently a work in progress by S. Kulkarni and G. Hormiga), we nevertheless preliminarily discuss the implications of the optimization of the respiratory system in the current phylogenetic hypotheses (see discussion below).

\section{Symphytognathidae}

Symphytognathidae, the traditionally called "lungless" spiders, currently comprise 90 described species in eight genera. The internal respiratory system has been described or depicted for only six species representing four genera: Symphytognatha globosa (Hickman, 1931: fig. 6; Forster, 1959: fig. 144), Patu samoensis (Marples, 1951), Anapistula secreta (Forster, 1958) Anapistula australia, Patu vitiensis (Forster, 1959: figs. 158 and 146, respectively), and Curimagua chapmani (Forster \& Platnick, 1977: fig. 22). The respiratory system of Symphytognatha picta was neither described nor illustrated, but scored in the morphological matrix of Lopardo and Hormiga (2015: characters 21-33). In their revision of the family, Forster and Platnick (1977) provided a summary of the respiratory system, including internal respiratory structures, at the generic level (i.e., for Anapistula, Curimagua, Globignatha, Patu, and Symphytognatha). Additionally, some information, mostly regarding external spiracle location, was provided for 15 additional species within the genera Anapistula (nine species; Harvey, 1998; Cardoso \& Scharff, 2009; Lin et al., 2009, 2013), Patu (two species; Lin \& Li, 2009; Lin et al., 2009) and Crassignatha (four species; Lin \& Li, 2009). Finally, four undescribed Patu species were scored and/or depicted in Forster (1959) and Lopardo and Hormiga (2015: figs. 114C, 117B, F, 120C, E). Summarizing, Symphytognathidae seem to comprise three different tracheal arrangements (Fig. 5, Table 1, and supplementary material), the most common one (present in all but one of the examined genera) consisting of anterior tracheae connected by a rigid transverse duct and entering the prosoma, and an absent posterior respiratory system. Anapistula and an undescribed species of Patu (from Western Samoa; see Forster, 1959) comprise a peculiar posterior tracheal system, similar to that of Mysmeninae and/or Synaphridae (see above), i.e., a wide and advanced tracheal spiracle consisting of two distant openings connected by a thin furrow. Internally, the tracheal arrangement consists of two bundles of seemingly lateral tracheae connected by an atrium and entering into the prosoma. The median tracheae/ entapophyses of Anapistula have not yet been observed. Lastly, we report a third tracheal arrangement observed in an undescribed Patu species from Dominican Republic, with a posterior tracheal system consisting of a single narrow posterior spiracle adjacent to the spinnerets, small atrium leading to two single lateral tracheae and a single unbranched (i.e., fused) seemingly median entapophysis (Fig. 4b). The respiratory system remains unknown for the genera Anapogonia, Crassignatha, and Iardinis.

\section{Theridiosomatidae}

This family of "large" symphytognathoids (their body length is usually over $1.5 \mathrm{~mm}$ ) includes to date 133 described species in 19 genera. Curiously, although the first account on the symphytognathoid internal respiratory system was performed for a theridiosomatid more than a century ago (Lamy, 1902) and given the relatively large amount of taxonomic literature available for this family (more than 80 references), merely nine publications describe in part (e.g., externally) or in more detail their respiratory configuration (Pickard-Cambridge, 1894; Fage, 1937; Marples, 1955; Coddington, 1986; Song et al., 1999; Jocqué \& Dippenaar-Schoeman, 2006; Labarque \& Griswold, 2014; Lopardo \& Hormiga, 2015; Prete et al., 2018). Furthermore, only four species in three genera are partially accounted for their internal respiratory system, as textual descriptions or illustrations: Theridiosoma gemmosum (Lamy, 1902: fig. 47; Lopardo \& Hormiga, 2015: fig. 123A), Theridiosoma lopdelli (Marples, 1955), Cuacuba mariana (Prete et al., 2018: fig. 8C), and Chthonos quinquemucronata (Fage, 1937). The respiratory system of Coddingtonia euryopoides was scored in the morphological matrix of Lopardo and Hormiga (2015) but not illustrated. The typical theridiosomatid respiratory arrangement consists of two book lungs, and a posterior narrow tracheal spiracle adjacent to the spinnerets and opening into two seemingly median entapophyses and two single lateral tracheae restricted to opisthosoma. This 
Fig. 4 The respiratory system of symphytognathoid spiders. Dorsal view. a Tasmanapis strahan (Anapidae), ARS with unconnected reduced book lungs and tracheal tubes arising from the leaves. b Patu-SYMP-001-DR (Symphytognathidae), overview of ARS and PRS, which consists of numerous tracheae. Note the single median entapophysis. c Coddingtonia euryopoides (Theridiosomatidae), overview of ARS and PRS. d Cepheia longiseta (Synaphridae), ARS with few tracheae and prominent transverse duct. Abbreviations: aTt, anterior tracheal tubes; $\mathrm{mE}$, median entapophysis; plT, posterior lateral trachea; rBL, reduced book lung; $\mathrm{Sp}$, spermatheca; TD, transverse duct; $\mathrm{Tt}$, tracheal tube
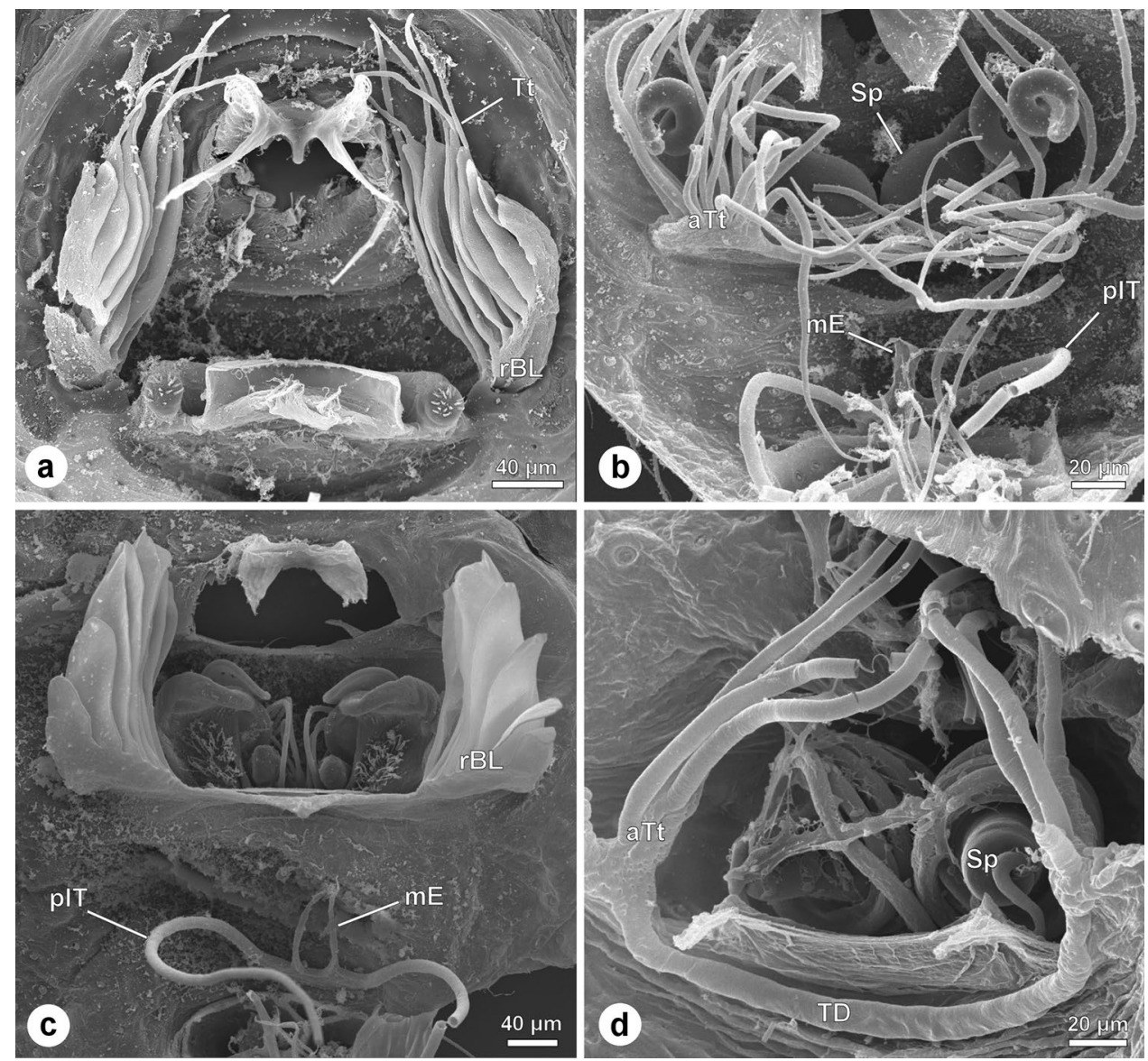

arrangement is presumed to be invariant across the family. Our findings on Coddingtonia euryopoides reveal a similar posterior respiratory arrangement, but the presence of reduced book lungs (Fig. 4c), suggesting that the family might show some diversity in respiratory arrangements awaiting further investigation. Unfortunately, the respiratory system of the majority of theridiosomatids remains unknown.

\section{Synaphridae}

Although its first species was described in 1881 (Simon, 1881:132), this relatively obscure and small family has lately benefited with very detailed morphological studies (Lopardo \& Hormiga, 2007; Lopardo et al., 2007; Miller, 2007; Marusik \& Zonstein, 2011). Synaphridae comprise to date only 13 described species in three genera, two of them (Africepheia and Cepheia) monotypic. However, the respiratory system has been described and depicted in detail for four species representing all three genera, and seems uniform within the family: Africepheia madagascariensis
(Miller, 2007: fig. 8), Cepheia longiseta (Lopardo \& Hormiga, 2007: figs. 30-31, 58-63; see also Lopardo \& Hormiga, 2015: fig. 107F), Synaphris saphrynis (Lopardo et al., 2007: figs. 30, 33-39; see also Lopardo \& Hormiga, 2015: fig. 110F), and Synaphris schlingeri (Miller, 2007: fig. 61). The respiratory system of synaphrids consists exclusively of tracheae. The anterior spiracles are connected to the epigastric furrow. Interiorly, the anterior tracheae are connected by a rigid transverse duct, with five tracheal tubes arising from each anterior spiracle, four oriented anteriorly toward the cephalothorax (Fig. 4d), one oriented laterally. The posterior tracheal system consists externally of two distant spiracular openings exteriorly connected by a thin ridge (i.e., one wide spiracular opening). The thin ridge leads to a deep, flat, membranous atrium, anteriorly ending in a rigid U-shaped canal that connects to the tracheal ducts. Two main tracheal bundles arise from the junction of the tracheal ducts and the $\mathrm{U}$-shaped atrial canal, one on each side, directing tracheoles mainly anteriorly. Both tracheal systems seem to extend into the prosoma (Fig. 5). 

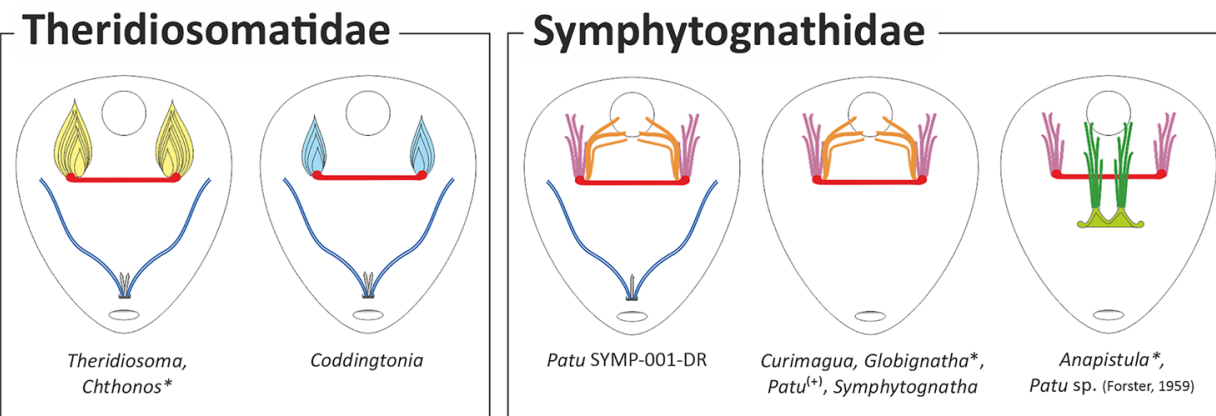

Synaphridae
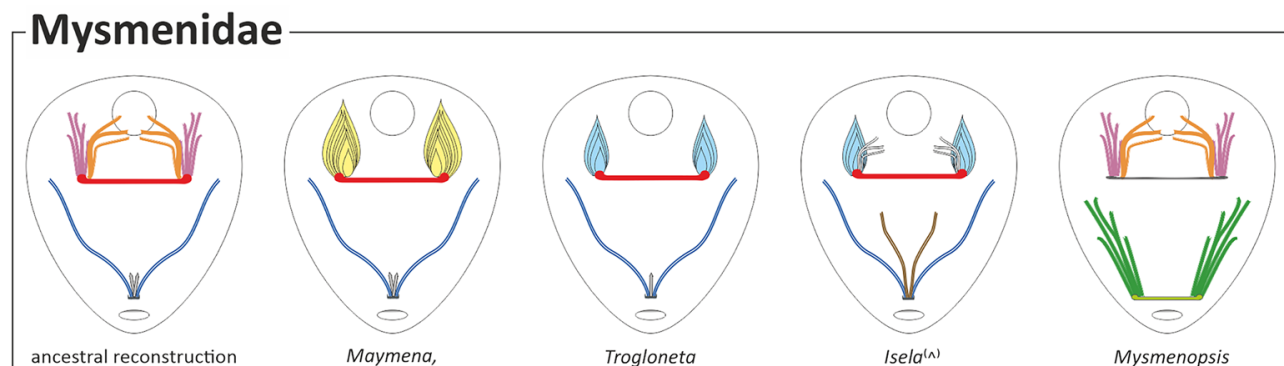

(but see M. dipluramigo, M. penai ${ }^{(\wedge)}$ )

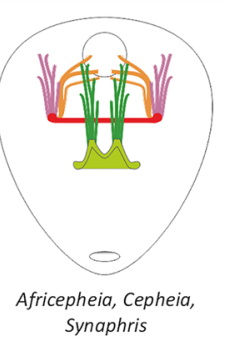

(Lestral reconstruction

(but see $M$.rica

Trogloneta

Iselan

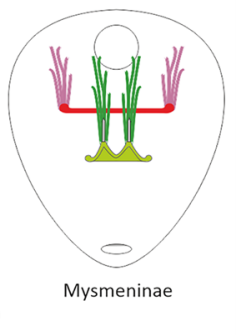

\section{Anapidae

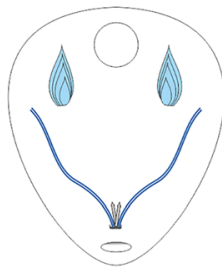

Comaroma, Zealanapis,

Risdonius*, (but see

Tasmanapis strahan ${ }^{(\lambda)(+)}$

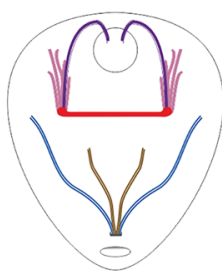

Micropholcomma

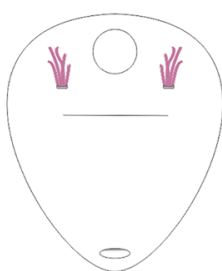

Caledanapis,

Mandanapis*

Montanapis* spiracles closest to pedicel:
Spinanapis

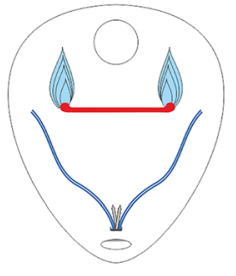

Crassanapis, Elanapis, Minanapis, Sheranapis* Teutoniella

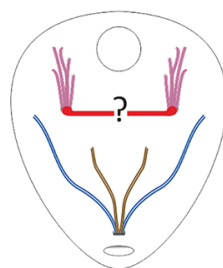

Sofanapis

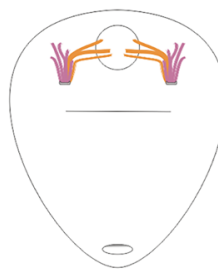

Chasmocephalon, Gertschanapis, Hickmanapis, Novanapis* Octanapis, Paranapis*

piracles closest to pedicel: Maxanapis, Nortanapis

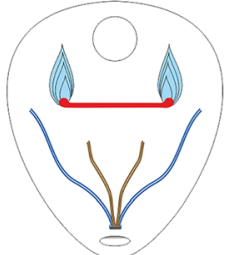

Gigiella, Queenslanapis* Tasmanapis $^{(+)}$ Victanapis

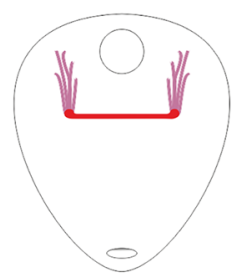

Acrobleps, Algidiella* Eperiella*, Epigastrina, Eterosonycha, Guiniella*, Holarchaea*, Normplatnickia* Pateliella*, Pecanapis* Raveniella, Rayforstia* Taliniella*, Tinytrella, Tricellina*

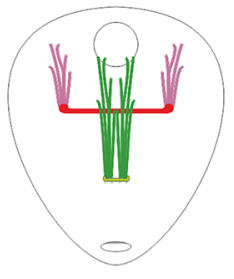

Anapis

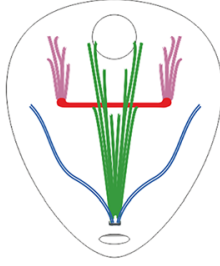

Anapisona $^{(+)}$

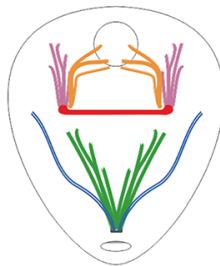

Anapisona hamigera ${ }^{(+)}$

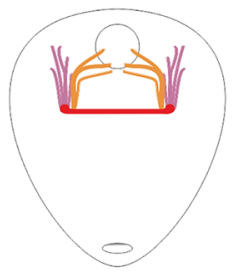

Paranapis $^{(+)}$, Zangherella minute posterior spiracle: Taphiassa and Olgania

narrow posterior spiracle: T. punctata and T. castanea

*: most likely arrangement

${ }^{(+)}$: two different arrangements ( ): combination of anterior respiratory units

Anterior respiratory modifications

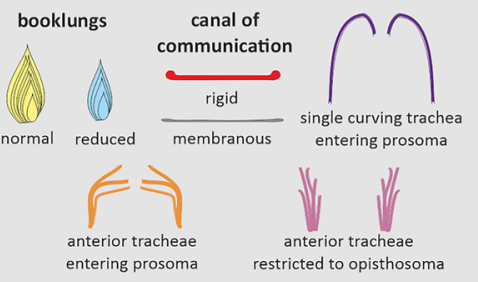

Posterior respiratory modifications
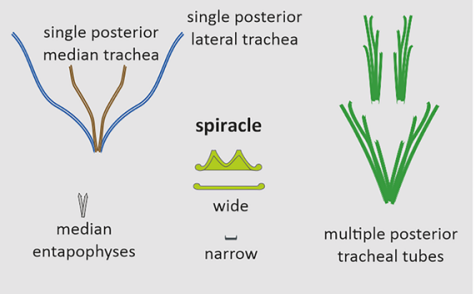
4Fig. 5 Schematic reconstructions depicting the diversity of respiratory arrangements of symphytognathoids, sorted by family. See bottom of figure for the sketches used to represent the different respiratory structures

\section{The bigger picture: the evolution of the respiratory system in symphytognathoids}

\section{General remarks}

Given the diversity of symphytognathoid anterior respiratory structures, some workers have hypothesized a trend of the "primitive" well-developed book lungs towards a reduction in leaf number and later its complete replacement by anterior tracheae (e.g., Forster, 1959, 1980; Gertsch, 1960; Levi, 1967; Levi \& Kirber, 1976). A comparable "simplification" event has also been suggested for the evolution of the posterior respiratory system of Araneomorphae (see Huckstorf et al., 2015 and Ramírez et al., 2021; and references therein).

Forster (1959:272) hypothesized that two separate posterior spiracles (i.e., the wide spiracle of Mysmeninae, Anapistula, and Synaphridae) leading into tracheae located midway between the spinnerets and the epigastric furrow was the ancestral condition of his Symphytognathidae $s$. $l$. (Anapidae + Mysmenidae + Symphytognathidae). To explain the diversity of the respiratory system in symphytognathoids, Forster (1959) proposed a pattern of changes related to the position and number of posterior tracheal spiracles, which involved the fusion of the two advanced spiracles into a single spiracle adjacent to the base of the spinnerets, to ultimately being lost (i.e., from complex to simple to absent).

We inferred the evolutionary transformations of the respiratory system of Mysmenidae and other symphytognathoid families based on the optimization of such characters onto the preferred optimal trees from Lopardo et al. (2011) and Kulkarni et al. (2021). Our optimizations offer different evolutionary hypotheses for both the anterior and posterior respiratory systems compared to the aforementioned hypotheses for symphytognathoids (Figs. 6 and 7). The reconstruction of the ancestral symphytognathoid respiratory system based on the total evidence analysis (Figs. 6 and 7) is as follows: anteriorly, fully developed book lungs connected by a transverse duct; posteriorly, tracheal system arising from one single narrow spiracle located at the spinnerets and internally consisting of two median apodemes and two lateral simple tracheae restricted to the opisthosoma, arranged separately in four tubes arising independently from the spiracle. This plesiomorphic respiratory arrangement is found in one species of the basal Theridiosomatidae (Theridiosoma gemmosum) and optimizes as homologous to that of the theridiid representative in this dataset, which is placed as either sister taxa of symphytognathoids (Fig. 6) or sister to a clade that includes all other araneoids (Fig. 7).
The plesiomorphic symphytognathoid arrangement seems to have re-evolved independently in the mysmenid Maymena. Furthermore, the reconstruction of the ancestral respiratory system of the ANTS (Anterior Tracheal System) clade on both the phylogenetic hypotheses of Lopardo et al. (2011) and Kulkarni et al. (2021) results in a similar arrangement to that reported as the mysmenid ancestral reconstruction (i.e., anterior tracheae extending into prosoma and connected by a transverse duct; posterior tracheae comprising a single narrow spiracle adjacent to spinnerets and internally a small atrium, median entapophyses and lateral tracheae restricted to the opisthosoma; Figs. 5-7; see above).

\section{Anterior respiratory system}

The anterior respiratory system of Theridiosomatidae reflects the plesiomorphic condition of symphytognathoids; however, the bulk of the respiratory diversity occurs in the remaining symphytognathoids excluding this early branching family (note, however, that the book lungs in one of the theridiosomatid representatives in this dataset, Coddingtonia euryopoides, became reduced). Character reconstructions based on both the phylogenetic hypotheses by Lopardo et al. (2011; Fig. 6) and Kulkarni et al., (2021; Fig. 7) imply that an anterior tracheal system extending into the prosoma and connected by a transverse duct evolved from fully developed book lungs in the ANTS Clade, which comprises all symphytognathoids excluding Theridiosomatidae. Hence, the anterior respiratory system seems to not have evolved in sequential steps of decreasing complexity of the book lungs towards tracheae as previously proposed (see above; e.g., Forster, 1959, 1980; Gertsch, 1960; Levi, 1967; Levi \& Kirber, 1976). Conversely, and although ambiguously optimized, reduced book lungs have originated independently at least twice from this homologous tracheal system present in most symphytognathoids. Reduced book lungs originating from tracheae evolved independently in a clade comprising the mysmenid genera Trogloneta, Maymena, and Isela, and also in most anapids. The ambiguity in the optimization tracing the fully developed book lungs of most Maymena species makes the delimitation of its origin and its ancestral condition uncertain. As mentioned above, reduced book lungs originate from fully developed book lungs only once, in Theridiosomatidae.

The optimization (not shown) of the anterior respiratory system as a binary character in the hypothesis of Kulkarni et al. (2021) produces a similar hypothesis with at least two independent regains of (reduced) anterior book lungs from tracheae: once within Mysmenidae at the base of the clade including Trogloneta, Mysmenopsinae (with a reversal to tracheae in Mysmenopsis), and Maymena (fully developed book lungs from reduced book lungs), and at least once within Anapidae (with a reversal to tracheae in Taphiassa 


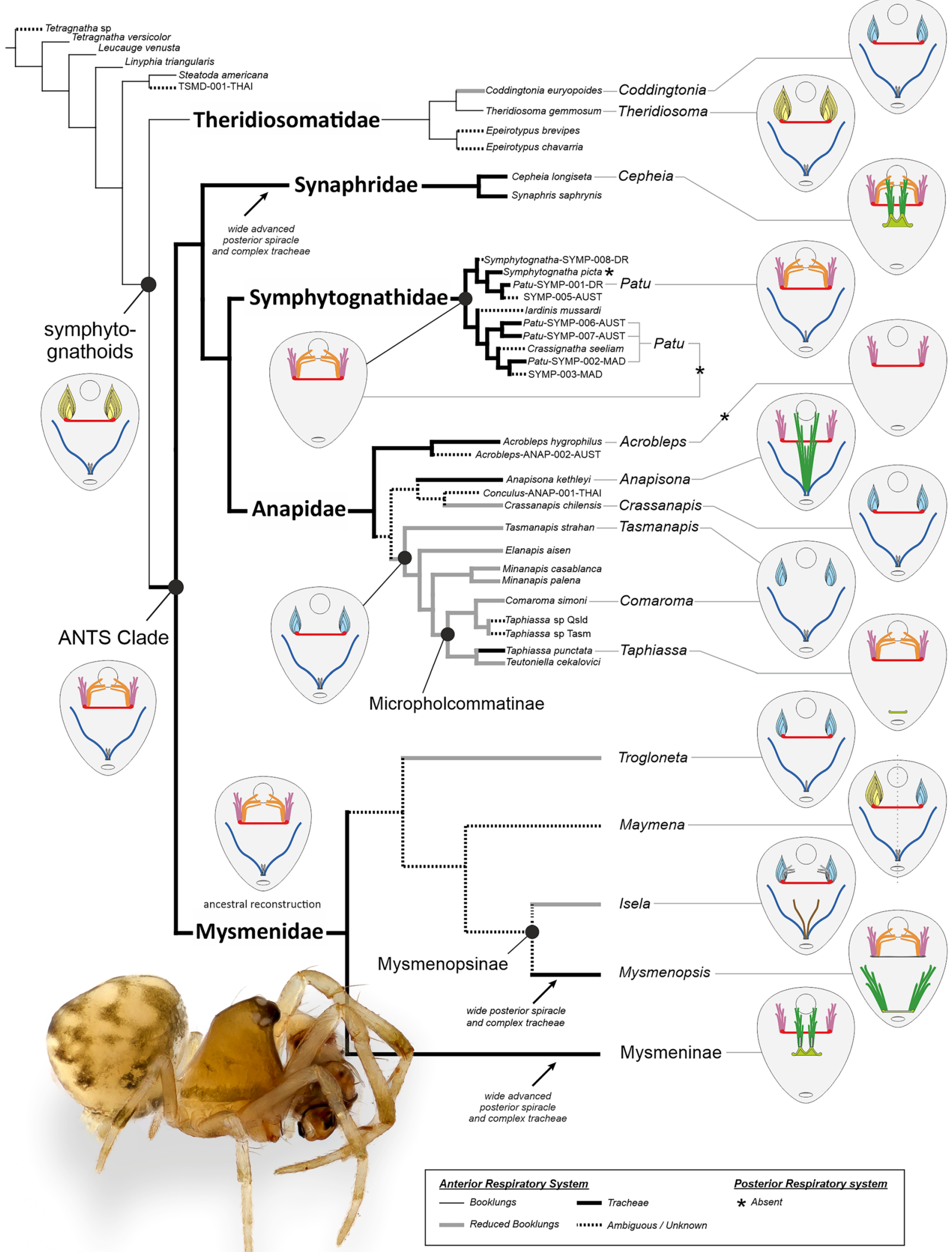


4Fig. 6 Phylogenetic hypothesis on the evolution of the respiratory system in symphytognathoids reconstructed on the total evidence cladogram of Lopardo et al., (2011: fig. 12). The tree has been simplified and the character state changes are optimized under parsimony (see text for details). Family codes used for unidentified species are as follows: ANAP, Anapidae; MYSM, Mysmenidae; SYMP, Symphytognathidae; TSMD, Theridiosomatidae. A male of Microdipoena guttata (Mysmeninae, Mysmenidae) from Comoros is depicted at the bottom of the figure

punctata). The optimization of the same binary character in the hypothesis of Lopardo et al. (2011) results in an ambiguous pattern of evolution at the familial level within Symphytognathoids; however, the optimization of this character suggests nevertheless a regain of (reduced) book lungs from tracheae at least once within Anapidae. Forcing homology of the anterior book lungs under a parsimony asymmetric evolutionary scenario resulted in a minimum loss/gain ratio of 100/49 (in the hypothesis of Lopardo et al., 2011) and 100/66 (in the hypothesis of Kulkarni et al., 2021) producing a reconstruction with plesiomorphic book lungs and seven independent origins of tracheae across both trees, i.e., one more step than under symmetric parsimony.

The non-homology of a relatively "complex" trait such as the book lungs as implied in the optimal reconstructions seems a controversial scenario. Forcing homology of book lungs at the cost of multiple instances of convergence of tracheal structures implies an evolutionary hypothesis where the transition to tracheae must be about one and a half to two times more likely than the reappearance of book lungs. In addition, the robustness of our results (like any phylogenetic analysis) is clearly taxonand topology-dependent. Alternative hypotheses of symphytognathoid non-monophyly based on molecular data (e.g., Dimitrov et al., 2012, 2017; Wheeler et al., 2017; Fernández et al., 2018; Kallal et al., 2021), where symphytognathoid families are mostly unrelated to each other, might provide a different hypothesis where the anterior book lungs are mostly the symplesiomorphic condition, with tracheae evolving independently in or within each family. An interesting exception might occur in the topologies in which Anapidae and Symphytognathidae are closely related (e.g., in the hypotheses of Dimitrov et al., 2012, 2017; Wheeler et al., 2017), the regain of book lungs could result, as is the case in our study, in a distal clade within Anapidae. Interestingly, different combinations of reduced book lungs plus anterior tracheae were observed in a few species (Lopardo \& Hormiga, 2015: character 21). In the anapid Tasmanapis strahan the reduced book lungs have a single trachea extending anteriorly on each leaf (Fig. 4a). In the mysmenopsine Isela sp. (Kilifina-MYSM-002-KENYA), the reduced book lungs have a clump of about six tracheae arising dorsally from the most dorsal leaf of the lungs (Fig. 2a, b). Finally, in Maymena rica only one tracheal tube arises from the most dorsal leaf of the reduced book lungs (Fig. 1d). Less evident, an opposite case occurs in some representatives of Mysmenopsis (M. dipluramigo and M. penai), where the anterior respiratory system is predominantly tracheal, except for a minute ventral leaf arising ventral to the tracheal tubes (Fig. 2e). These unusual and different combinations of respiratory units could represent intermediate stages and therefore could potentially enlighten the understanding of the evolutionary transformations from one structure to the other, in these particular cases from tracheae to the regain of book lungs. It appears that structurally similar book lungs can originate from different processes of tracheal transformation. On one hand, it could occur simultaneously, where each tracheal tube modifies into a leaf (e.g., anapids), and on the other hand, it could occur sequentially, where the tracheal modifications start ventrally and advance dorsally (e.g., mysmenids). The implications of these two potential pathways in the development of book lungs remain unknown.

\section{Posterior respiratory system}

The evolution of the posterior respiratory arrangement of the ANTS Clade (i.e., Forster's "Symphytognathidae" sensu lato: Anapidae + Mysmenidae + Symphytognathidae, also including Synaphridae and Micropholcommatinae in the explored dataset) differ from the hypothesis proposed by Forster (1959): the diversity of tracheal systems originates from one single narrow spiracle located adjacent to the spinnerets, and not from a wide and advanced tracheal spiracle located halfway between the spinnerets and the epigastric furrow. Based on our analysis, the wide spiracle originates independently at least two times from a narrow one (plus most likely two additional times in Anapistula and in Anapis), and in only one of these occasions the spiracle remains adjacent to the spinnerets (i.e., in Mysmenopsis). A wide spiracle entails a more complex, branching posterior tracheal system (but not vice versa, see below), the origin of such complex system is ambiguously optimized for Synaphridae and Mysmeninae. Although the loss of the posterior tracheal system in most symphytognathids and the early branching anapid genus Acrobleps is ambiguously optimized, it seems to have occurred from a narrow posterior spiracle as well. The diversity of posterior tracheal arrangements encompasses those already described for Mysmenidae as well a few additional ones (see Fig. 5):

- Two long lateral tracheal tubes and two shorter median apodemes arising independently from a narrow posterior 


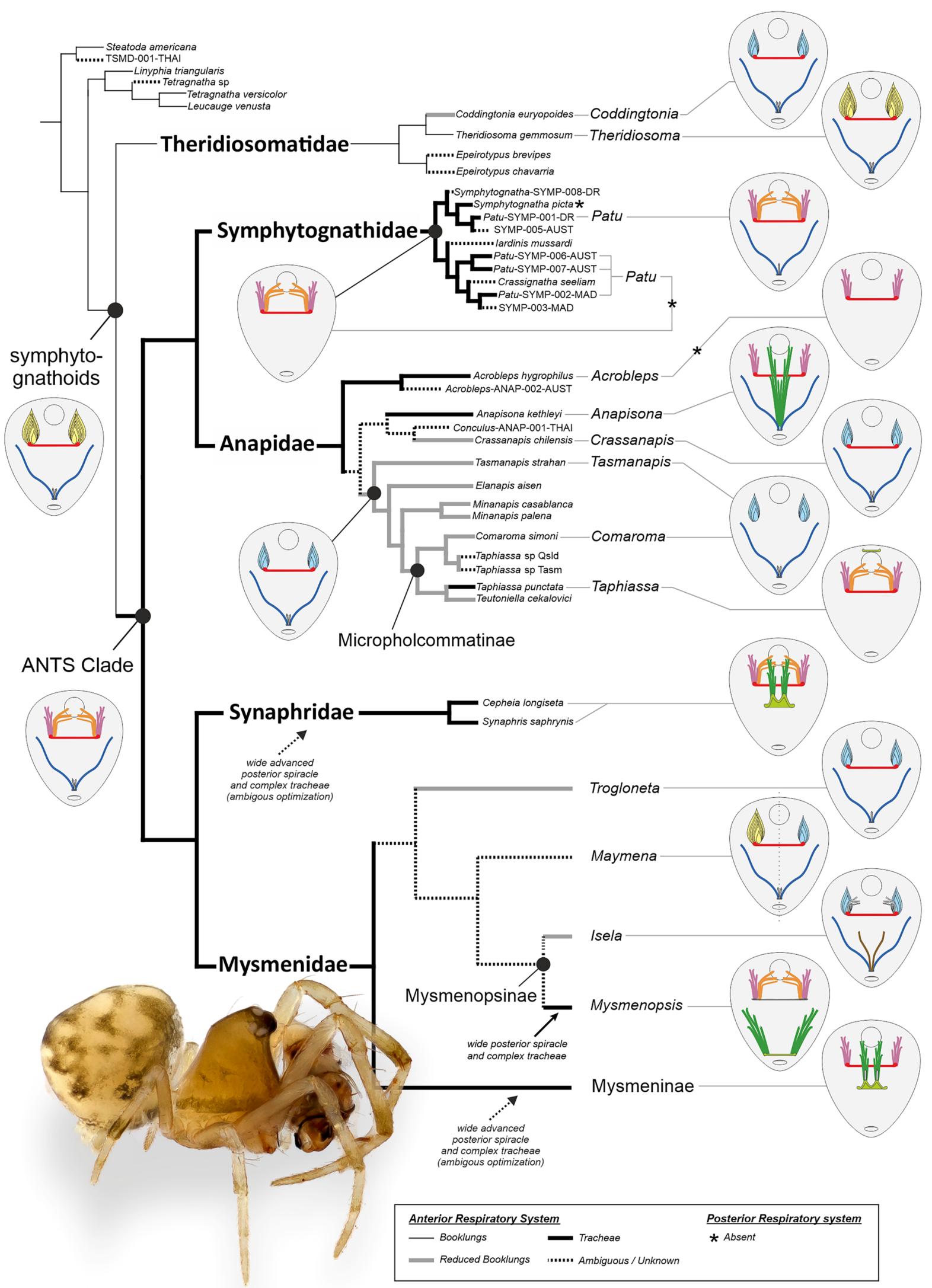


4Fig. 7 Phylogenetic hypothesis on the evolution of the respiratory system in symphytognathoids reconstructed on the total evidence cladogram of Lopardo et al., (2011: fig. 12) with interfamilial relationships taken from the UCE phylogeny of Kulkarni et al., (2021: fig. 4b). Intrafamilial relationships are simplified and follow Lopardo et al., (2011: fig. 12), as in Fig. 6, and the character state changes are optimized under parsimony (see text for details). Family codes used for unidentified species are as follows: ANAP, Anapidae; MYSM, Mysmenidae; SYMP, Symphytognathidae; TSMD, Theridiosomatidae. A male of Microdipoena guttata (Mysmeninae, Mysmenidae) from Comoros is depicted at the bottom of the figure

single atrium/spiracle (Maymena, Theridiosomatidae, and some Anapidae) (Figs. $1 \mathrm{~b}$ and $4 \mathrm{c}$ );

- Two single (i.e., unbranched) lateral tracheae confined to abdomen and one single unbranched (fused) median apodeme from a narrow posterior atrium/spiracle (Trogloneta and Patu-SYMP-001-DR) (Figs. If and 4b);

- One narrow posterior atrium/spiracle connected to four long unbranching tracheal tubes (corresponding to two median and two lateral tracheal tubes) confined to the abdomen (Isela, some Anapidae) (Fig. 2a);

- One wide posterior atrium/spiracle (i.e., adjacent to spinnerets) connected to two long tracheal tubes (most likely lateral) or two bundles of lateral branching tracheoles arising at each end of the posterior atrium/spiracles and seemingly restricted to the abdomen (the median structures are absent) (Mysmenopsis) (Fig. 2f);

- A wide advanced spiracle (i.e., not adjacent to spinnerets) connected to a M-shaped atrium, where two bundles of lateral branching tracheae arise, most of these tracheoles extending into the prosoma, each surrounding a vestigial median apodeme (Mysmeninae, maybe Anapistula, possibly also Anapis) (Fig. 3b-e);

- The complete loss of the posterior tracheae (most Symphytognathidae and Anapidae);

- Median and lateral tracheae sharing a common basal trunk, resulting in two bundles arising from the atrium (Synaphridae);

- Median tracheal trunks branching into two bundles of narrow tracheoles extending into the prosoma (or not), and two simple unbranched lateral tracheae (Anapisona), in a tracheal arrangement similar to that described as "desmitracheate" for some linyphiids (see, e.g., Lamy, 1902; Blest, 1976; Millidge, 1984, 1986; Hormiga, 1994, 2000; Arnedo et al., 2009) (but note that all studied linyphiids have anterior book lungs).

Given the extraordinary morphological diversity of the respiratory organs of symphytognathoids (in particular those within the ANTS Clade), the task of discerning the definite pattern of evolutionary transformations appears challenging. However, there seems to be a tendency, as implied by the results of the combined phylogenetic hypotheses, for the posterior respiratory system (in which the plesiomorphic condition is a relatively simple structure arising from a posterior narrow spiracle) to become either a highly complex tracheal system (also advanced and usually extending into the prosoma), or completely lost, a pattern in agreement to what has been hypothesized for Araneomorphae in general (Ramírez et al., 2021).

\section{Potential factors driving the evolution of respiratory structures in symphytognathoids}

\section{General remarks}

In general, symphytognathoids with reduced book lungs seem to have retained a simple posterior tracheal arrangement, whereas taxa with an anterior tracheal system appear to either have evolved a complex, branching posterior tracheal system or have lost it. A number of hypotheses have attempted to explain the diversification of spider respiratory organs, although few have included symphytognathoid taxa. It is out of the scope of this study to propose or even test such hypotheses, but we provide an overview of some of the factors that may play a role in the evolutionary changes of the respiratory system of symphytognathoids.

Physiological explanations have focused on the degree of development of either the anterior book lungs or posterior tracheal system (i.e., not in the transformation of anterior book lungs into tracheae), since the taxa examined in previous studies have well developed anterior book lungs and diverse posterior tracheal systems (Uloboridae, Opell, 1990, 1998; Filistatidae \& Araneidae, Anderson \& Prestwich, 1982; Salticidae \& Lycosidae, Schmitz \& Perry, 2000, 2001, 2002; Schmitz, 2004, 2005; see Schmitz, 2016). In taxa with a dual respiratory system, the book lungs oxygenate the hemolymph and the tracheal system carries oxygen directly to the tissues. The walls of the whole tracheal system, however, can function as gas exchange surfaces and provide oxygen not only directly to the tissues, but also to the hemolymph; the tracheae of spiders have been therefore termed "tubular" or "tracheal lungs" (Forster, 1959; Schmitz \& Perry, 2000, 2001).

\section{Web-building}

The relationship between metabolic processes and webbuilding has been scarcely explored. Opell $(1990,1998)$ has shown that in hackled orb weavers (Uloboridae) respiration with the anterior book lungs and the posterior tracheae are complementary, suggesting that the posterior tracheal system meets more specific oxygen demands, possibly related to a more intensive manipulation of webs and/or prey subduing. Arnedo et al. (2009:253) posed the possibility that the complex branching tracheal system of most erigonine 
linyphiids, the so-called desmitracheate pattern (Millidge, 1984), could be somehow linked to differences in web architecture. There are two main types of sheet webs in linyphioids, "aerial" and "substrate" webs typical of many erigonines. These authors argued that "It is tempting to speculate about a causal connection between the transition from aerial into substrate webs and the modification of the simple haplotracheate pattern into a desmitracheate system, based on the energetic differences of monitoring these different types of web." Unfortunately, Arnedo et al. (2009:253) concluded, neither the required detailed phylogenetic hypothesis nor the biological data needed to establish in more detail, and ultimately test, such hypothesis are yet available. More recently, Ramírez et al. (2021) have hypothesized that in araneomorph spiders the posterior tracheae evolved to supply the demands of the spinning system, ultimately associated to the evolution of aerial webs.

A relationship between variation in the web architecture and respiratory organs is not evident in symphytognathoids. Identical webs are built by species with different respiratory systems: e.g., compare Maymena, Acrobleps, Crassanapis and Anapisona; or those of Symphytognathidae, Elanapis and Tasmanapis. In addition, different webs are built by taxa with similar respiratory systems: e.g., compare Acrobleps and most symphytognathids; and in particular compare the relatively simple respiratory arrangement of Maymena and Theridiosoma gemmosum and the different degree of manipulation of their webs (see Lopardo and Hormiga (2015) for a discussion on symphytognathoid web evolution and Eberhard (2020) for a review of symphytognathoid web architecture). Mysmeninae species have a well-developed tracheal system and also build highly complex tri-dimensional webs, whereas synaphrids and the symphytognathid Anapistula have a complex, branching tracheal system but build sheets or planar orbs, respectively (Eberhard, 2020). Furthermore, kleptoparasitic symphytognathoids (described at least once in Anapidae and Symphytognathidae, common in Mysmenopsinae) are reported to share a similar lifestyle that involves limited web and prey manipulation, yet have different respiratory arrangements, consisting of mostly tracheal system (Forster \& Platnick, 1977; Platnick \& Shadab, 1978; Vollrath, 1978; Griswold, 1985; Müller, 1987; Baert \& Murphy, 1987; Coyle \& Meigs, 1989; Baert, 1990; Eberhard et al., 1993; Ramírez \& Platnick, 1999; Lopardo \& Hormiga, 2015; Dupérré \& Tapia, 2015, 2020). For example, in Sofanapis the anterior tracheae are restricted to the opisthosoma and complemented by two lateral plus two median posterior tracheal tubes; in Curimagua anterior tracheae enter the prosoma and the posterior system is absent; Mysmenopsis has a well-developed anterior and posterior tracheal systems, and its sister mysmenopsine genus Isela has reduced book lungs and two lateral plus two median posterior tracheal tubes. As discussed above, the general respiratory pattern of symphytognathoids is either anterior book lungs with simple posterior tracheae, well-developed anterior and posterior tracheae, or relatively well-developed anterior tracheae and lacking a posterior system. These arrangements do not appear to match the complementarity of respiratory structures suggested for uloborids.

In Salticidae and Lycosidae (two well-known families of cursorial spiders with different degrees of complexity of the tracheal system), it has been shown that well-developed posterior tracheae extending into the prosoma may play an important role in gas exchange during high metabolic demands, whereas poorly developed tracheae (i.e., as in Lycosidae) might play no role at all but could be of some importance in local oxygen supply or overall carbon dioxide release, respectively (Schmitz, 2005). No physiological data exist for symphytognathoid spiders, and therefore based only on superficial morphology and behavior, it is not known whether these minute spiders have comparable oxygen demands, or fit this proposed pattern, especially when the life histories of these aforementioned families are so dissimilar to the web-building or kleptoparasitic symphytognathoids. However, it was hypothesized that the increased metabolic rates in orb weavers are likely related to their life style and ecology (Canals et al., 2015) and it was empirically shown that in Araneus diadematus oxygen consumption nearly doubled during web-building (Peakall \& Witt, 1976). Thus, even though there is no obvious correlation between web architecture and the respiratory system anatomy, it can be hypothesized that the evolution of the respiratory organs of symphytognathoids is influenced by the energy demands of web-building (see also Ramírez et al., 2021). In addition, although a potential correlation between diversification rates and the development of tracheae remains to be studied and tested (Dimitrov \& Hormiga, 2021), it might be worth to point out that the kleptoparasitic subfamily Mysmenopsinae (comprising only two genera) might prove a good starting point for comparative studies: the African genus Isela (two species described) has reduced book lungs and simple posterior tracheae, in contrast with the American genus Mysmenopsis (52 species described, almost all reported to be kleptoparasitic) which has well-developed anterior and posterior tracheal systems.

\section{Body size and other systems}

Spiders show the largest range of body size among Arachnida, ranging from the miniscule symphytognathids to the impressive size of some theraphosids (Mammola et al., 2017). The smallest spider species belongs to the family Symphytognathidae: the smallest adult females spider 
recorded is Anapistula ataecina with $0.43 \mathrm{~mm}$, and the smallest adult male spider is Patu digua with $0.37 \mathrm{~mm}$ (Cardoso \& Scharff, 2009; Forster \& Platnick, 1977). In general, spiders with a posterior tracheal system are on average smaller than those with two pairs of book lungs (Dunlop, 2019). However, it is not evident whether this is a direct consequence of body size, nor how the process of miniaturization affects this correlation (Schütt, 2003; Dunlop, 2019). For example, a link between smaller body size and further reduction of the book lungs (i.e., in number of leaves) is unclear for symphytognathoids, in particular given that the current phylogenetic hypotheses (e.g., Kallal et al., 2021; Kulkarni et al., 2021) imply that "reduced" book lungs have originated from anterior tracheae. Also, given their inherent minute size, any correlation between symphytognathoid body size and anterior book lung leaf number might be expected to be susceptible to the decimals of millimeters. As reported in the present study, that might not be entirely the case: minute species with a body size of $2 \mathrm{~mm}$ (as measured in females, relatively "large" symphytognathoids, e.g., theridiosomatids and the mysmenid genera Isela and Maymena) are found to have from eight to more than 20 book lung leaves (also $2 \mathrm{~mm}$ Mysmenopsis species have a relatively well-developed anterior tracheal system); small species (e.g., Maymena mayana, female body size $2.5-2.9 \mathrm{~mm}$ ) also have around 20 book lung leaves; and conversely minute symphytognathoids with a body size of $1.3 \mathrm{~mm}$ can have between 8 and 12 book lung leaves (e.g., Maymena rica, Tasmanapis); Crassanapis chilensis, with a body size larger than $1.5 \mathrm{~mm}$, has eight leaves); and so on. Arnedo et al. (2009) observed that in Araneoidea (the ecribellate orb weavers), complex branching tracheal systems are primarily found in groups that are of small size, that often live in the leaf litter and that are not necessarily each other's closest relatives. In addition to symphytognathoids, branching tracheal systems are found in linyphiids (mainly in erigonines and "micronetines"; Blest, 1976; Millidge, 1984, 1986; Hormiga 2000), in some tetragnathids (e.g. Glenognatha; Alvarez-Padilla \& Hormiga, 2011; Cabra-García \& Brescovit, 2016), and cyatholipids (Davies, 1978; Forster, 1988; Griswold, 2001; although most cyatholipids build aerial webs in vegetation or on tree trunks, some are litter dwellers, such as Matilda species in Western Australia). To our knowledge, the only group of medium to large sized araneoids with a complex, branching tracheal system are the tetragnathid species of the genus Nanometa (Alvarez-Padilla \& Hormiga, 2011; Alvarez-Padilla et al., 2020).

It has been observed that in arachnids with centralized respiratory organs (i.e., book lungs), the oxygenated hemolymph is distributed to the tissues via highly complex arterial systems, whereas apulmonate arachnids (i.e., with decentralized respiratory organs, also smaller in size) display a reduction in their arterial systems where tubular tracheae supply directly the tissues with oxygen. This functional correlation between the respiratory and the circulatory system suggests an evolutionary trend within Arachnida of the reduction of the book lungs and the elaborated vascular systems into a tracheal system and a more simplified circulatory system, seemingly occurring several times independently (see Wirkner et al., 2013 and Klußmann-Fricke \& Wirkner, 2018; and references therein). A similar trend has been suggested within Araneomorphae where at in at least four independent instances the modifications of the posterior book lungs into tracheae is correlated with the reduction of the number of heart ostia (i.e., the loss of the 4th ostium; see Huckstorf et al., 2015 and references therein), or vice versa. The independent re-gain of both structures in Hypochilidae and in Austrochiloidea seems unlikely (Huckstorf et al., (2015; see also Ramírez et al., 2021). The current symphytognathoid phylogenetic hypotheses suggest that secondary reduced book lungs have originated at least twice independently from tracheae and that the whole respiratory system within these minute spiders seems to be undergoing rapid evolutionary changes. Unfortunately, the fine details and diversity, and its potential functional correlation with the circulatory system in symphytognathoids is unknown (see also Dunlop, 2019).

It has been proposed that a decrease in body size is inversely correlated to metabolic rate, and that in minute spiders, the replacement of the anterior book lungs by tracheae might have evolved to cope with higher metabolism but also to prevent water loss (e.g., Levi, 1967; Levi \& Kirber, 1976; Schmitz, 2016). Most symphytognathoids are relatively similar in body size and are found with few exceptions mostly in humid places, and have a respiratory system not necessarily consisting of tracheae. Also, as mentioned above, some symphytognathoids build similar webs but have different overall respiratory arrangements and vice versa; therefore, water loss by itself cannot explain such diversity in the respiratory organs of symphytognathoids. Physiologically, the size of the (anterior) book lungs in terms of surface and volume is directly proportional to the metabolic rates of the spider (Anderson \& Prestwich, 1982; but also intrinsically proportional to body size, Anderson \& Prestwich, 1980), although it is not clear how the metabolic rates are affected by body size. Depending on their position, tracheae provide spiders with a more flexible respiratory behavior, as "tracheal lungs" to increase respiratory surface area, or for local oxygen demands via terminal diffusion (Schmitz, 2016). One aspect affecting the metabolic rates of minute spiders is the size of their nervous system. Size, and particularly miniaturization, have an impact in the structure and function of the nervous system. Very small spiders are 
reported to possess relatively large central nervous systems, which occupy proportionally a larger volume of the cephalothorax and extend into the coxae, and may also be related in the ventral deformation of the sternum (the typical "domed" sternum of symphytognathoids) (Eberhard \& Wcislo, 2011; Quesada et al., 2011). For example, the central nervous system of Anapisona simoni (Anapidae) and Mysmena sp. (Mysmenidae) juveniles comprises $77.8 \%$ and $63 \%$, respectively, of the cephalothorax volume (Quesada et al., 2011). Such morphological distortions have been presumed to minimize behavioral deficits related to very small nervous systems (Eberhard, 2007, 2011; Eberhard \& Wcislo, 2011; Quesada et al., 2011). In addition, minute spiders may have reached the minimum possible neuronal cell body diameter (Quesada et al., 2011). Nervous tissue is metabolically expensive to maintain, and in some spiders the tracheal system is especially responsible for providing oxygen to this system (Schmitz, 2004, 2005, 2016); this might be especially so in very small animals and their relatively large costly brains (Eberhard \& Wcislo, 2011) and would explain the large number of tracheae from the anterior and/or posterior respiratory system reaching into the prosoma. As stated in Lopardo and Hormiga (2015), the reduction in size might be chosen as a tempting explanation for most of features observed in these minute spiders (e.g., spinneret spigot conformation, circulatory system; see Lopardo \& Hormiga, 2015 and Dunlop, 2019, respectively). Should size alone be an important factor, ontogeny may prove useful to tests such correlation, with spiderlings showing differences in the complexity of their respiratory systems compared to adults of the same species. However, factors other than miniaturization might be acting in concert to promote such diversification of respiratory systems. So far, no evident correlated pattern of evolution is perceived among these minute families.

\section{Conclusions}

The respiratory system of symphytognathoid spiders is very diverse not only across families, but also highly variable within them. In symphytognathoids, the anterior tracheal system extending into the prosoma and connected by a transverse duct evolved from fully developed book lungs. Conversely, reduced book lungs have evolved independently twice from anterior tracheae. It appears that structurally similar book lungs can originate from different evolutionary pathways of tracheal transformation, although intraspecific and ontogenetic variation should be studied to better understand these transitions. A wide posterior spiracle has evolved independently at least twice from a narrow one, becoming advanced (located halfway between the spinnerets and the epigastric furrow) in at least two occasions (both the width and the location of the posterior spiracle are ambiguously optimized for synaphrids and mysmenines). There seems to be a tendency in symphytognathoids, as implied by the phylogenetic reconstructions explored in this study, for the posterior respiratory system to become either a highly complex and branched tracheal system (e.g., in some mysmenids and anapids) or to be lost altogether (e.g., in some symphytognathids). So far, no single phenotypic trait, such as size, habitat preference, natural history, web and/or prey manipulation, web architecture, etc., can satisfactorily explain the diversity of respiratory organs in symphytognathoids, but more likely a combination of several factors might be driving phenotypic variation of the tracheal system. This diversity of systems might not be exclusively environmentally shaped, but rather a phylogenetic component might also be involved.

\section{Appendix}

List of specimens examined and reported in the present study.

\section{Anapidae}

Comaroma simoni. AUSTRIA: Carinthia, Weissensee, Kleiner Silbergraben, 1150 m asl; July 7, 1991; C. Komposch leg., $\widehat{\partial}$ 오 (GWU, Kropf donation); no data, H. Franz leg, slg. H. Wiehle, . (SMF 11456/5).

Sheranapis villarrica. CHILE: Región IX (Araucanía): Malleco Prov.: Mon. Nat. Contulmo, 19-21.xii.1998, Ramírez, Compagnucci, Grismado, Lopardo, ô우 (MACNAr 10381).

Tasmanapis strahan. AUSTRALIA: Tasmania: FranklinGordon Wild Rivers N.P., Nothofagus rainforest, Nelson Falls, $15.0 \mathrm{~km} 089^{\circ}$ E Queenstown, S42 $06^{\prime} 13.9^{\prime \prime}$ E145 $44^{\prime} 10.0^{\prime \prime}$, 338 m, 9.iii.2006, Ramírez, Griswold, Hormiga, Lopardo, Scharff, Silva, Boutin, Szüts, ㅇ (MACN-Ar 11536); Newall Creek, $9.57 \mathrm{~km} 177^{\circ} \mathrm{S}$ Queenstown, $\mathrm{S} 42^{\circ} 09^{\prime} 37.1^{\prime \prime} \mathrm{E} 145^{\circ}$ 32' 20.1", 159 m, 10.iii.2006, G. Hormiga, L. Lopardo, ${ }^{3}$ (GWU).

\section{Mysmenidae}

Isela sp. (as Kilifina -MYSM-002-KENYA). KENYA: Kwale, $30 \mathrm{~km} \mathrm{~S}$ Mombasa, 12.xi.1992, on diplurids webs, $\mathrm{V} \& \mathrm{~B}$ Roth, $39^{\circ} 40^{\prime} \mathrm{E} 4^{\circ} 10^{\prime} \mathrm{S}, 8$ 우 $70^{\wedge} 2$ juvs (CAS, MYSM-0020).

Maymena ambita. USA: Virginia, Stafford Co., Falmouth, mixed deciduous forest, 27.vi.1978, H,L\&F Levi, ô (MCZ 51259, SEM); Alabama: Madison Co., Aladdin Cave, Sharp's Cave, AF Archer, 1.xii.1939, ㅇ (AMNH, SEM); Tuscaloosa 
Co., Tuscaloosa, River Rd \& Guild Woodo Rd, hollow logs, 4.vii.1981, J Coddington, $1 \mathrm{sub}+1$ juv (MCZ 51256); 우 (MCZ 51254).

Maymena mayana. GUATEMALA: Alta Vera Paz, Gruta de Lanquin, 6.ii.1980, B-V. Roth, 4 ㅇ $\lesssim$ (CAS). MEXICO: Veracruz, Municipio de Atoyac, Grutas de Atoyac, $18.9215^{\circ} \mathrm{N} 96.7653^{\circ} \mathrm{W}$, A. Gluesenkamp C. Savvas P. Sprouse E. Gonzalez O. Francke, 22.ix.2004, 460 m, in cave, 5 ㅇ 2 (AMNH, AGG 951, ATOL, 95\% etOH).

Maymena rica. COSTA RICA: Heredia, Organization for Tropical Studies field station at Finca La Selva, near Puerto Viejo, on West River Road, general, 10.i.1982, J. Coddington, $4 \lesssim 2$ ㅇ (MCZ 53351).

Microdipoena guttata. USA: Virginia, Page Co. Rileyville, Sheridan School Mtn. Campus N38 43' 49.2": W $78^{\circ} 22^{\prime} 58.8^{\prime \prime}$, 300 m, 29.vii.2006, L. Lopardo, D. Dimitrov, ํํㅇ (MCZ, several specimens). COMOROS: Mayotte, Majimbini, maison de la Convalescence, ruines, 21.ii.1998, forest, sieved litter, R Jocque, 2へ̂ (MRAC, MYSM-0067). CÔTE D'IVOIRE: Appouesso, forêt classée de la Bossematié, rain forest, pitfall traps, R Jocque \& N Séabé, station B,C,D,F, 19.ix.1994, $6{ }^{\Uparrow}$ (MRAC, MYSM-0076).

Mysmena woodwardi. NEW GUINEA, AI Valley, Nomdugl, West Highlands, ex moss, rain forest, ca. $6500 \mathrm{ft}$, T.E. Woodward $q$ holotype (QM).

Mysmena MYSM-005-ARG. ARGENTINA: Misiones, P.N. Iguazú: Sendero Macuco y Picadas aledañas, 18-21.i.2005, manual (coll. Grismado, Lopardo, Piacentini, Quaglino,

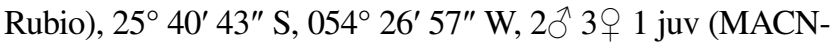
Ar, MYSM-0101).

Mysmena MYSM-010-MEX. MEXICO: Chiapas, Ocosingo, Ejido Nueva Palestina, Benito Juárez, Reserva

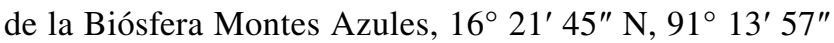
W, MAP 150 m., 24.x.2005, F. Alvarez, L. Lopardo \& J. Castelo leg., 5 + (GWU/MCZ, 80\%ethanol, LLS-067).

Mysmena MYSM-015-MAD. MADAGASCAR: Antananarivo: R.S. d' Ambohitantely, Forêt d' Ambohitantely, primary forest, ca. $20.9 \mathrm{~km} 72^{\circ} \mathrm{NE}$ d'Ankazobe, $18^{\circ} 13^{\prime} 30.3^{\prime \prime}$ $\mathrm{S}, 47^{\circ} 16^{\prime} 44^{\prime \prime} \mathrm{E}$, Elev. 1574 m, montane rainforest, General coll., 20-21.iii.2003, Ldd, D.Andriamalala, D.Silva, et al., DSD0040, 15 $13 \hat{\jmath}$ 5juv (CASENT 9015033, 75\% ethanol, LLS-020, LLS-021).

Mysmena MYSM-028-MAD. MADAGASCAR: Antsiranana: Reserve Speciale d'Ambre, $3.5 \mathrm{~km} 235^{\circ}$ SW Sakaramy, 26-31.i.2001, 12 ${ }^{\circ} 28^{\prime} 8^{\prime \prime} \mathrm{S}, 4^{\circ} 14^{\prime}$ 32" E, Elev. $325 \mathrm{~m}$, tropical dry forest, general coll. Day, J.J.Rafanomezantsoa et al., JJR0115 (CAS), 5 우 (CASENT 9004610, 75\% ethanol, LLS-025).

Mysmeninae MYSM-008-ARG. ARGENTINA: Misiones, San Pedro, P. Prov. Cruce Caballero, 13-16.i.2005, CC-Salto, manual, $26^{\circ} 28^{\prime} 00^{\prime \prime} \mathrm{S}, 053^{\circ} 58^{\prime} 00^{\prime \prime} \mathrm{W}$, coll. Grismado, Lopardo, Piacentini, Quaglino, Rubio, 5 ㅇ (MYSM-0105, LLS-070), 1 q (MYSM-0090), 1 juv (MYSM-0092) (MACN-Ar-80\% ethanol); NE San
Pedro, 27-29.x.1995, manual, M.J. Ramírez, 1ð (MACNAr, MYSM-0117); P.N. Iguazú, area Cataratas, 11-16. xii1999, manual, M.J. Ramírez \& L. Lopardo, 1 ㅇ 1 juv (MACN-Ar, MYSM-0134); P.N. Iguazú, isla, paseos superiores, 8-15.ii.1995, manual, M.J. Ramírez, 1 ㅇ (MACN-Ar, MYSM-0136); Saltos del Uruguaí, 10 km N Puerto Libertad, 23-25.ii.1997, manual, M.J. Ramírez, 4 ㅇ 1juv (MACN-Ar, MYSM-0140); INTA San Vicente, 10 km N San Vicente, 26.i.1997, manual, M.J. Ramírez, $3 \bigcirc 2 \precsim 2$ juv (MACN-Ar, MYSM-0143).

Mysmeninae MYSM-009-MAD. MADAGASCAR: Antananarivo: $3 \mathrm{~km} 41^{\circ} \mathrm{NE}$ Andranomay, $11.5 \mathrm{~km} 147^{\circ}$ SSE Anjozorobe, 5-13.xii.2000, $18^{\circ} 28^{\prime} 24^{\prime \prime} \mathrm{S}, 4^{\circ} 57^{\prime}$ 36" E, Elev. $1300 \mathrm{~m}$, montane rainforest, general collecting, C.E. Griswold et al., BLF2543, 8 ㅇ $1 \hat{\sigma} 1$ juv (CASENT 9004228, 75\% ethanol, LLS-017, LLS-018).

Mysmenopsis dipluramigo. PANAMA: Coclé, $5 \mathrm{mi}$.

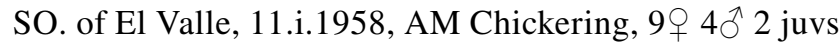
(MCZ 51292, MYSM-0043).

Trogloneta cantareira. BRAZIL: Sao Paulo, Cotia, Reserva do Morro Alto, 18-28.vi.2002, Equipe Biota col., 궁 (USNM, ex IBSP 59785, MYSM-0169); 우 (USNM, ex IBSP 59786, MYSM-0170).

Trogloneta granulum. CZECH REPUBLIC: South Bohemia (Jihočeský Kraj), Blanský Les Protected Landscape Area, Vysoká Běta, 780-790 m, 5.ix.2006, J. Hajer, V. Růžička, ộ (GWU, J. Hajer donation).

\section{Synaphridae}

Cepheia longiseta. FRANCE: Gallia; coll. Simon; 4538, b.849, 14 ๆ $18 ð 3$ juv paralectotypes (MNHN-AR1059, MYSM-0171); Banyuls, no collector, đ̊ sub ô (MNHN, MYSM-0177). ITALY: South Tirol, Bolzano Province, Bolzano/Guntschna[=Guncinà], 27.vi.1988, 470, Noflatscher, 2 ㅇ $\widehat{\jmath}$ (NMW 14994, MYSM-0176). No locality data, no collector, $\widehat{\jmath}$ (MNHN, MYSM-0178).

\section{Theridiosomatidae}

Coddingtonia euryopoides. THAILAND: Chiang Mai Prov., Doi Inthanon NP, cloud forest, Kew Mae Pan Nature trail, N $18^{\circ} 33^{\prime} 19.9^{\prime \prime}$; E $98^{\circ}$ 28' 56.4", 2170 m, 4-5.X.2003, ATOL Expedition 2003, 5 ○े (USNM); $2 \operatorname{sub} \widehat{\jmath}$ (USNM, 95\% ethanol, LLS-043); 1 ha. inventory, ca. $500 \mathrm{~m}$ from checkpoint at intersect. rd. summit/Mae Chaem, wet primary forest, $\mathrm{N} 18^{\circ}$ 31' 47.9"; E $98^{\circ} 30^{\prime}$ 9.0", ca. 1800 m, 6-7.X.2003, ATOL Expedition 2003, q (USNM, 95\% ethanol, LLS-052). 
Supplementary Information The online version contains supplementary material available at https://doi.org/10.1007/s13127-021-00524-w.

Acknowledgements We are indebted to Gonzalo Giribet, Charles E. Griswold, James M. Clark, Diana L. Lipscomb, Marc W. Allard, Fernando Álvarez-Padilla, Martín J. Ramírez, Dimitar S. Dimitrov, Ligia R. Benavides Silva, and Siddharth S. Kulkarni for support and/or discussions. We are grateful to Martín J. Ramírez, Cristian J. Grismado, Luis A. Compagnucci, Luis Piacentini, Gonzalo Rubio, Ana Quaglino, Fernando Álvarez-Padilla, José Luis Castelo-Calvillo, Charles E. Griswold, Robert J. Raven, Nikolaj Scharff, Diana Silva-Dávila, Lisa Joy Boutin, Tamás Szüts, and Dimitar S. Dimitrov for their help in the field. Our thanks extend to the following colleagues and institutions for kindly providing the precious specimens examined in this study: Charles E. Griswold (California Academy of Sciences, San Francisco, USA); Christian Kropf (Department of Invertebrates, Natural History Museum Bern, Switzerland); Christine Rollard and Elise-Anne Leguin (Muséum National d'Histoire Naturelle, Paris, France); Gonzalo Giribet and Laura Leibesperger (Museum of Comparative Zoology, Harvard University, Cambridge, USA); Jaromir Hajer (Department of Biology, University J.E. Purkinje, Ustí nad Labem, Czech Republic); Jonathan A. Coddington (National Museum of Natural History, Smithsonian Institution, Washington DC, USA); Jürgen Gruber (Naturhistorisches Museum, Vienna, Austria); Martín J. Ramírez and Cristina Scioscia (Museo Argentino de Ciencias Naturales "Bernardino Rivadavia", Buenos Aires, Argentina); Nikolaj Scharff (Zoological Museum, University of Copenhagen, Denmark); the late Norman I. Platnick, and Lou Sorkin (American Museum of Natural History, New York, USA); Robert J. Raven (Queensland Museum, Brisbane, Australia); and Rudy Jocqué (Musee Royal Afrique Centrale, Tervuren, Belgium). We are thankful to an anonymous reviewer and particularly Martín J. Ramírez for useful comments and careful, critical reading of our manuscript.

Author Contribution Not applicable.

Funding Open Access funding enabled and organized by Projekt DEAL. Funding for this research has been provided by grants from the US National Science Foundation (DEB-0328644, DEB 1144492, and DEB 114417) to GH and Gonzalo Giribet, grants DEB 1754289, 1754278, and DEB 1754262 to GH, Gonzalo Giribet and Sarah Boyer, and by a NSF AToL grant (EAR-0228699) to W. Wheeler, J. Coddington, GH, L. Prendini, and P. Sierwald. Additional support was provided by a Weintraub Fellowship and a Research Enhancement Fund from The George Washington University (to GH), by a Sigma-Xi Grant-inAid of Research (to Martín J. Ramírez, Luis A. Compagnucci and LL), and a Cosmos Club Foundation Program of Grants-In-Aid to Young Scholars (to LL).

Data Availability Supplementary data will be also available as dataset within the World Spider Trait database (https://spidertraits.sci.muni. $\mathrm{cz} /)$.

Code Availability Not applicable.

\section{Declarations}

Conflict of Interest The authors declare no competing interests.

Open Access This article is licensed under a Creative Commons Attribution 4.0 International License, which permits use, sharing, adaptation, distribution and reproduction in any medium or format, as long as you give appropriate credit to the original author(s) and the source, provide a link to the Creative Commons licence, and indicate if changes were made. The images or other third party material in this article are included in the article's Creative Commons licence, unless indicated otherwise in a credit line to the material. If material is not included in the article's Creative Commons licence and your intended use is not permitted by statutory regulation or exceeds the permitted use, you will need to obtain permission directly from the copyright holder. To view a copy of this licence, visit http://creativecommons.org/licenses/by/4.0/.

\section{References}

Álvarez-Padilla, F., \& Hormiga, G. (2008). A protocol for digesting internal soft tissues and mounting spiders for scanning electron microscopy. Journal of Arachnology, 35, 538-542.

Álvarez-Padilla, F., \& Hormiga, G. (2011). Morphological and phylogenetic atlas of the orbweaving spider family Tetragnathidae (Araneae: Araneoidea). Zoological Journal of the Linnean Society, 162(4), 713-880.

Álvarez-Padilla, F., Kallal, R. J., \& Hormiga, G. (2020). Taxonomy and phylogenetics of nanometinae and other Australasian orb-weaving spiders (Araneae: Tetragnathidae). Bulletin of the American Museum of Natural History, 438, 1-107.

Anderson, J., \& Prestwich, K. (1980). Scaling of subunit structures in book lungs of spiders (Araneae). Journal of Morphology, 165, $167-174$.

Anderson, J., \& Prestwich, K. (1982). Respiratory gas exchange in spiders. Physiological Zoology, 55(1), 72-90.

Arnedo, M. A., Hormiga, G., \& Scharff, N. (2009). Higher-level phylogenetics of linyphiid spiders (Araneae, Linyphiidae) based on morphological and molecular evidence. Cladistics, 25(3), 231-262.

Baert, L., \& Murphy, J. (1987). Kilifia inquilina, a new mysmenid spider from Kenya (Araneae, Mysmenidae). Bulletin of the British Arachnological Society, 7, 194-196.

Baert, L. (1982). Spiders (Araneae) from Papua New Guinea III. Mysmenidae (Symphytognathoidea). Bulletin of the British Arachnological Society, 5, 303-308.

Baert, L. (1984). Mysmenidae and Hadrotarsidae from the Neotropical Guaraní zoogeographical province (Paraguay and south Brasil) (Araneae). Revue Suisse De Zoologie, 91, 603-616.

Baert, L. (1988). The Ochyroceratidae and Mysmenidae from Sulawesi (Araneae). Indo-Malayan Zoology, 5, 9-22.

Baert, L. (1989). Mysmenidae from Rwanda (Araneae). Revue Zoologique Africaine, 103, 29-33.

Baert, L. (1990). Mysmenidae (Araneae) from Peru. Bulletin De L'institut Royal Des Sciences Naturelles De Belgique, Entomologie, 60, 5-18.

Balogh, J., \& Loksa, I. (1968). The scientific results of the Hungarian soil zoological expeditions to South America. 7. Arachnoidea. Description of Brasilian spiders of the family Symphytognathidae. Acta Zoologica Hungarica, 14, 287-294.

Banks, N. (1895). A list of the spiders of Long Island; with descriptions of new species. Journal of the New York Entomological Society, 3, 76-93.

Barrows, W. M. (1940). New and rare spiders from the Great Smoky Mountain National Park region. Ohio Journal of Science, 40, 130-138.

Bertkau, P. (1889). Interessante Tiere aus der Umgebung von Bonn. Verhandlungen Des Naturhistorischen Vereins Der Preussischen Rheinlande Und Westfalens, 46, 69-82.

Blest, A. D. (1976). The tracheal arrangement and the classification of linyphiid spiders. Journal of Zoology, 180(2), 185-194. 
Brescovit, A. D., \& Lopardo, L. (2008). The first record on the spider genus Trogloneta Simon in the southern hemisphere (Araneae, Mysmenidae), with descriptions of three new species from Brazil and remarks on the morphology. Acta Zoologica (stockholm), 89, 93-106.

Brignoli, P. M. (1981). New or interesting Anapidae (Arachnida, Araneae). Revue Suisse De Zoologie, 88, 109-134.

Bromhall, C. (1987). Spider tracheal systems. Tissue and Cell, 19(6), 793-807.

Butler, L. S. G. (1932). Studies in Australian spiders. No. 2. Proceedings of the Royal Society of Victoria, 44, 103-117.

Cabra-García, J., \& Brescovit, A. D. (2016). Revision and phylogenetic analysis of the orb-weaving spider genus Glenognatha Simon, 1887 (Araneae, Tetragnathidae). Zootaxa, 4036(1), $1-183$.

Canals, M., Veloso, C., Moreno, L., \& Solis, R. (2015). Low metabolic rates in primitive hunters and weaver spiders. Physiological Entomology, 40, 232-238. https://doi.org/10.1111/phen.12108

di Caporiacco, L. (1949). L'aracnofauna della Romagna in base alle raccolte Zangheri. Redia, 34, 237-288.

Cardoso, P., \& Scharff, N. (2009). First record of the spider family Symphytognathidae in Europe and description of Anapistula ataecina sp. n. (Araneae). Zootaxa, 2246, 46-57.

Chamberlin, R. V., \& Ivie, W. (1938). Araneida from Yucatan. Publications, Carnegie Institution of Washington, 491, 123-136.

Coddington, J. A. (1986). The genera of the spider family Theridiosomatidae. Smithsonian Contributions to Zoology, 422, 1-96.

Coddington, J. A. (1990). Ontogeny and homology in the male palpus of orb-weaving spiders and their relatives, with comments on phylogeny (Araneoclada: Araneoidea, Deinopoidea). Smithsonian Contributions to Zoology, 496, 1-52.

Coyle, F. A., \& Meigs, T. E. (1989). Two new species of kleptoparasitic Mysmenopsis (Araneae, Mysmenidae) from Jamaica. Journal of Arachnology, 17, 59-70.

Crosby, C. R., \& Bishop, S. C. (1927). New species of Erigoneae and Theridiidae. Journal of the New York Entomological Society, 35, 147-154.

Davies, V. T. (1978). A new family of spiders (Araneae: Teemenaaridae). Symposia of the Zoological Society of London, 42, 293-302.

Dimitrov, D., \& Hormiga, G. (2021). Spider diversification through space and time. Annual Review of Entomology, 66(1), 225-241.

Dimitrov, D., Benavides, L.R., Arnedo, M.A., Giribet, G., Griswold, C.E., Scharff, N. \& Hormiga, G. (2017). Rounding up the usual suspects: a standard target-gene approach for resolving the interfamilial phylogenetic relationships of ecribellate orb-weaving spiders with a new family-rank classification (Araneae, Araneoidea). Cladistics 33(3), 221-250 \& Suppl. https://doi.org/10. 1111/cla.12165

Dimitrov, D., Lopardo, L., Giribet, G., Arnedo, M.A., Álvarez-Padilla, F. \& Hormiga, G. (2012). Tangled in a sparse spider web: single origin of orb weavers and their spinning work unravelled by denser taxonomic sampling. Proceedings of the Royal Society B, Biological Sciences 279, 1341-1350 \& Suppl. 1-5. https://doi. org/10.1098/rspb.2011.2011

Dingerkus, G., \& Uhler, L. (1977). Enzyme clearing of alcian blue stained whole small vertebrates for demonstration of cartilage. Stain Technology, 52, 229-232.

Dunlop, J. (2019). Miniaturisation in Chelicerata. Arthropod Structure \& Development., 48, 20-34. https://doi.org/10.1016/j.asd.2018. 10.002

Dupérré, N., \& Tapia, E. (2015). Descriptions of four kleptoparasitic spiders of the genus Mysmenopsis (Araneae, Mysmenidae) and their potential host spider species in the genus Linothele (Araneae, Dipluridae) from Ecuador. Zootaxa, 3972(3), 343-368.
Dupérré, N., \& Tapia, E. (2020). Megadiverse Ecuador: A review of Mysmenopsis (Araneae, Mysmenidae) of Ecuador, with the description of twenty-one new kleptoparasitic spider species. Zootaxa, 4761(1), 1-81.

Eberhard, W. G., \& Wcislo, W. T. (2011). Grade changes in brainbody allometry: Morphological and behavioural correlates of brain size in miniature spiders, insects and other invertebrates. In J. Casas (Ed.), Advances in Insect Physiology (Vol. 60, pp. 155-214). Academic Press.

Eberhard, W. G. (2007). Miniaturized orb-weaving spiders: Behavioural precision is not limited by small size. Proceedings of the Royal Society B, 274, 2203-2209. https://doi.org/10.1098/rspb. 2007.0675

Eberhard, W. G. (2011). Are smaller animals behaviourally limited? Lack of clear constraints in miniature spiders. Animal Behaviour, 81(4), 813-823. https://doi.org/10.1016/j.anbehav.2011.01.016

Eberhard, W. G. (2020). Spider webs: Behavior, function, and evolution. University of Chicago Press.

Eberhard, W. G., Platnick, N. I., \& Schuh, R. T. (1993). Natural history and systematics of arthropod symbionts (Araneae; Hemiptera; Diptera) inhabiting webs of the spider Tengella radiata (Araneae, Tengellidae). American Museum Novitates, 3065, 1-17.

Fage, L. (1937). A propos de quelques nouvelles araignées apneumones. Bulletin De La Société Zoologique De France, 62, 93-106.

Feng, C. C., Miller, J. A., Lin, Y. C., \& Shu, Y. F. (2019). Further study of two Chinese cave spiders (Araneae, Mysmenidae), with description of a new genus. ZooKeys, 870, 77-100.

Fernández, R., Kallal, R. J., Dimitrov, D., Ballesteros, J. A., Arnedo, M. A., Giribet, G., \& Hormiga, G. (2018). Phylogenomics, diversification dynamics, and comparative transcriptomics across the spider tree of life. Current Biology, 28(9), 1489-1497.e5.

Foelix, R. (2011). Biology of spiders (3rd ed.). Oxford University Press.

Forster, R. R., \& Platnick, N. I. (1977). A review of the spider family Symphytognathidae (Arachnida, Araneae). American Museum Novitates, 2619, 1-29.

Forster, R. R., \& Platnick, N. I. (1981). A textricellid spider from Chile (Araneae, Textricellidae). Bulletin of the American Museum of Natural History, 170, 263-270.

Forster, R. R., \& Platnick, N. I. (1984). A review of the archaeid spiders and their relatives, with notes on the limits of the superfamily Palpimanoidea (Arachnida, Araneae). Bulletin of the American Museum of Natural History, 178, 1-106.

Forster, R. R. (1951). New Zealand spiders of the family Symphytognathidae. Records of the Canterbury Museum, 5, 231-244.

Forster, R. R. (1955). Spiders of the family Archaeidae from Australia and New Zealand. Transactions and Proceedings of the Royal Society of New Zealand, 83, 391-403.

Forster, R. R. (1958). Spiders of the family Symphytognathidae from North and South America. American Museum Novitates, 1885, $1-14$.

Forster, R. R. (1959). The spiders of the family Symphytognathidae. Transactions and Proceedings of the Royal Society of New Zealand, 86, 269-329.

Forster, R.R. (1980). Evolution of the tarsal organ, the respiratory system, and the female genitalia in spiders. In J. Gruber (Ed.), Proceedings of the 8th International Congress of Arachnology (pp. 269-284). H. Egermann: Vienna.

Forster, R. R. (1988). The spiders of New Zealand: Part VI. Family Cyatholipidae. Otago Museum Bulletin, 6, 7-34.

Forster, R. R. (1970). The spiders of New Zealand. Part III. Otago Museum Bulletin, 3, 1-184.

Gertsch, W. J., \& Davis, L. I. (1936). New spiders from Texas. American Museum Novitates, 881, 1-21.

Gertsch, W. J. (1941). Report on some arachnids from Barro Colorado Island, Canal Zone. American Museum Novitates, 1146, 1-14. 
Gertsch, W. J. (1960). Descriptions of American spiders of the family Symphytognathidae. American Museum Novitates, 1981, 1-40.

Goloboff, P., Farris, J., \& Nixon, K. (2008). TNT, a free program for phylogenetic analysis. Cladistics, 24, 774-786.

Griswold, C. E. (1985). Isela okuncana, a new genus and species of kleptoparasitic spider from southern Africa (Araneae: Mysmenidae). Annals of the Natal Museum, 27, 207-217.

Griswold, C. E. (2001). A monograph of the living world genera and Afrotropical species of cyatholipid spiders (Araneae, Orbiculariae, Araneoidea, Cyatholipidae). Memoirs of the California Academy of Sciences, 26, 1-251.

Griswold, C. E., Coddington, J. A., Hormiga, G., \& Scharff, N. (1998). Phylogeny of the orb-web building spiders (Araneae, Orbiculariae: Deinopoidea, Araneoidea). Zoological Journal of the Linnean Society, 123, 1-99.

Griswold, C.E., Ramírez, M.J., Coddington, J.A. \& Platnick, N.I. (2005). Atlas of phylogenetic data for entelegyne spiders (Araneae, Araneomorphae, Entelegynae), with comments on their phylogeny. Proceedings of the California Academy of Sciences 4th Series 56(Supplement II), 1-324.

Harvey, M. S. (1992). A new species of Symphytognatha Hickman (Araneae: Symphytognathidae) from Western Australia. Records of the Western Australian Museum, 15, 685-689.

Harvey, M. S. (1998). A review of the Australasian species of Anapistula Gertsch (Araneae: Symphytognathidae). Records of the Western Australian Museum, 19, 111-120.

Hickman, V. V. (1931). A new family of spiders. ProcEedings of the Zoological Society of London (b), 1931, 1321-1328.

Hickman, V. V. (1939a). On a dipneumone spider (Risdonius parvus, gen. et sp. n.), the female of which has reduced palpi. Proceedings of the Zoological Society of London (b), 108, 655-660.

Hickman, V.V. (1939b). Opiliones and Araneae. In: B.A. New Zealand Antarctic Research Expedition 1929-1931. Reports-Series B. Adelaide 4(5), 157-188.

Hickman, V. V. (1944). On some new Australian Apneumonomorphae with notes on their respiratory system. Papers and Proceedings of the Royal Society of Tasmania, 1943, 179-195.

Hickman, V. V. (1945). A new group of apneumone spiders. Transactions of the Connecticut Academy of Arts and Sciences, 36, $135-157$.

Hickman, V. V. (1979). Some Tasmanian spiders of the families Oonopidae, Anapidae and Mysmenidae. Papers and Proceedings of the Royal Society of Tasmania, 113, 53-79.

Hormiga, G., \& Griswold, C. E. (2014). Systematics, Phylogeny, and Evolution of Orb-Weaving Spiders. Annual Review of Entomology, 59(1), 487-512.

Hormiga, G. (1994). Cladistics and the comparative morphology of linyphiid spiders and their relatives (Araneae, Araneoidea, Linyphiidae). Zoological Journal of the Linnean Society, 111, $1-71$.

Hormiga, G. (2000). Higher-level phylogenetics of erigonine spiders (Araneae, Linyphiidae, Erigoninae). Smithsonian Contributions to Zoology, 609, 1-160.

Huckstorf, K., Michalik, P., Ramírez, M. J., \& Wirkner, C. S. (2015). Evolutionary morphology of the hemolymph vascular system of basal araneomorph spiders (Araneae: Araneomorphae). Arthropod Structure \& Development, 44, 609-621.

Jocqué, R. \& Dippenaar-Schoeman, A.S. (2006). Spider families of the world. Tervuren, Belgium: Musée Royal de l'Afrique Central Tervuren.

Kallal, R. J., Kulkarni, S. K., Dimitrov, D., Benavides, L. R., Arnedo, M. A., Giribet, G., \& Hormiga, G. (2021). Converging on the orb: Denser taxon sampling elucidates spider phylogeny and new analytical methods support repeated evolution of the orb web. Cladistics, 37(3), 298-316. https://doi.org/10.1111/cla.12439
Kamenz, C., \& Prendini, L. (2008). An Atlas of Book Lung Fine Structure in the Order Scorpiones (Arachnida). Bulletin of the American Museum of Natural History, 2008(316), 1-359.

Kamenz, C., Dunlop, J. A., \& Scholtz, G. (2005). Characters in the book lungs of Scorpiones (Chelicerata, Arachnida) revealed by scanning electron microscopy. Zoomorphology, 124(2), 101-109. https://doi.org/10.1007/s00435-005-0115-1

Klußmann-Fricke, B.-J., \& Wirkner, C. S. (2018). Same but different: A stunning analogy between tracheal and vascular supply in the CNS of different arachnids. Organisms, Diversity and Evolution, 18(2), 225-239.

Koch, L. (1877). Verzeichniss der bei Nürnberg bis jetzt beobachteten Arachniden (mit Ausschluss der Ixodiden und Acariden) und Beschreibungen von neuen, hier vorkommenden Arten. Abhandlungen Der Naturhistorischen Gesellschaft Zu Nürnberg, 6, 113-198.

Komatsu, T. (1940). On five species of spiders found in the Ryûgadô Cave. Tosa Province. Acta Arachnologica, 5(3), 186-195.

Kratochvíl, J. (1935). Araignées cavernicoles de Krivošije. Práce Moravské Přírodovědecké Společnosti, 9(12), 1-25.

Kraus, O. (1955). Spinnen aus El Salvador (Arachnoidea, Araneae). Abhandlungen Der Senckenbergischen Naturforschenden Gesellschaft, 493, 1-112.

Kraus, O. (1967). Zur Spinnenfauna Deutschlands, II. Mysmena jobi n. sp, eine Symphytognathide in Mitteleuropa (Arachnida: Araneae: Symphytognathidae). Senckenbergiana Biologica, 48, 387-399.

Kropf, C. (1995). Pseudanapis hoeferi, n. sp. from central Amazonia, Brazil (Araneae, Anapidae). Bulletin of the British Arachnological Society, 10, 19-22.

Kulkarni, S. K., Kallal, R. J., Wood, H. M., Dimitrov, D., Giribet, G., \& Hormiga, G. (2021). Interrogating genomic-scale data to resolve recalcitrant nodes in the Spider Tree of Life. Molecular Biology and Evolution, 38(3), 891-903. https://doi.org/10. 1093/molbev/msaa251

Kulkarni, S. K., Wood, H. M., Lloyd, M., \& Hormiga, G. (2020). Spider-specific probe set for ultraconserved elements offers new perspectives on the evolutionary history of spiders (Arachnida, Araneae). Molecular Ecology Resources, 20(1), 185-203. https://doi.org/10.1111/1755-0998.13099

Küntzel, N., Dunlop, J. A., \& Scholtz, G. (2019). Morphology and evolution of spider book lungs (Araneae). Arthropod Systematics \& Phylogeny, 77(2), 267-284.

Labarque, F.M. \& Griswold, C.E. (2014). New ray spiders from Southeast Asia: the new Philippine genus Tagalogonia gen. nov. and continental genus Coddingtonia Miller, Griswold and Yin, 2009 (Araneae: Theridiosomatidae), with comments on their intergeneric relationships. In: G.C. Williams \& T.M. Gosliner (Eds.), The Coral Triangle: The 2011 Hearst Philippine Biodiversity Expedition (pp. 407-425). California Academy of Sciences, San Francisco.

Lamy, E. (1902). Recherches anatomiques sur les trachees des Araignées. Annales des sciencies naturelles, Zoologie 15, 149-280.

Levi, H. W., \& Kirber, W. (1976). On the Evolution of Tracheae in Arachnids. Bulletin of the British Arachnological Society, $3(7), 187-188$

Levi, H. W. (1956). The spider genus Mysmena in the Americas (Araneae, Theridiidae). American Museum Novitates, 1801, $1-13$.

Levi, H. W. (1957). The North American spider genera Paratheridula, Tekellina, Pholcomma and Archerius (Araneae: Theridiidae). Transactions of the American Microscopical Society, 76(2), $105-115$.

Levi, H. W. (1967). Adaptations of respiratory systems of spiders. Evolution, 21, 571-583. 
Lin, Y. C., \& Li, S. Q. (2009). First described Patu spiders (Araneae, Symphytognathidae) from Asia. Zootaxa, 2154, 47-68.

Lin, Y. C., Pham, D. S., \& Li, S. Q. (2009). Six new spiders from caves of northern Vietnam (Araneae: Tetrablemmidae: Ochyroceratidae: Telemidae: Symphytognathidae). Raffles Bulletin of Zoology, 57, 323-342.

Lin, Y. C., Tao, Y., \& Li, S. Q. (2013). Two new species of the genus Anapistula (Araneae, Symphytognathidae) from southern China. Acta Zootaxonomica Sinica, 38, 53-58.

Lopardo, L., \& Hormiga, G. (2007). On the Synaphrid Spider Cepheia longiseta (Simon 1881) (Araneae, Synaphridae). American Museum Novitates, 3575, 1-18.

Lopardo, L., \& Hormiga, G. (2008). Phylogenetic placement of the Tasmanian spider Acrobleps hygrophilus (Araneae, Anapidae) with comments on the evolution of the capture web in Araneoidea. Cladistics, 24(1), 1-33.

Lopardo, L., \& Hormiga, G. (2015). Out of the twilight zone: Phylogeny and evolutionary morphology of the orb-weaving spider family Mysmenidae, with a focus on spinneret spigot morphology in symphytognathoids (Araneae, Araneoidea). Zoological Journal of the Linnean Society, 173(3), 527-786. https://doi.org/ 10.1111/zoj.12199

Lopardo, L., \& Michalik, P. (2013). First description of a mysmenid spider species from mainland Australia and new data for Mysmena tasmaniae Hickman, 1979 (Araneae, Mysmenidae). Memoirs of the Queensland Museum, Nature, 58, 381-396.

Lopardo, L., Giribet, G. \& Hormiga, G. (2011). Morphology to the rescue: Molecular data and the signal of morphological characters in combined phylogenetic analyses - A case study from mysmenid spiders (Araneae, Mysmenidae), with comments on the evolution of web architecture. Cladistics 27(3), 278-330 \& Supplementary material. https://doi.org/10.1111/j.1096-0031.2010.00332.x

Lopardo, L., Hormiga, G., \& Melic, A. (2007). Spinneret spigot morphology in synaphrid spiders (Araneae, Synaphridae), with comments on the systematics of the family and description of a new species of Synaphris Simon 1894 from Spain. American Museum Novitates, 3556, 1-26.

Mammola, S., Michalik, P., Hebets, E. A., \& Isaia, M. (2017). Record breaking achievements by spiders and the scientists who study them. PeerJ, 5, e3972. https://doi.org/10.7717/peerj.3972

Marples, B. J. (1951). Pacific symphytognathid spiders. Pacific Science, $5,47-51$.

Marples, B. J. (1955). Spiders from Western Samoa. Journal of the Linnean Society of London (zoology), 42(287), 453-504.

Marusik, Y. M., \& Zonstein, S. (2011). A synopsis of east-Mediterranean Synaphris Simon, 1894 (Araneae, Synaphridae) with a description of a new species from Israel. ZooKeys, 82, 35-44.

Meckel, J.Fr. (1809). Bruchstücke aus der Insectenanatomie. In: Beyträge zur vergleichenden Anatomie. Band 1, Heft 2, pp. 105-131, Leipzig.

Michalik, P. M., \& Ramírez, M. J. (2014). Evolutionary morphology of the male reproductive system, spermatozoa and seminal fluid of spiders (Araneae, Arachnida) - Current knowledge and future directions. Arthropod Structure \& Development, 43, 291-322. https://doi.org/10.1016/j.asd.2014.05.005

Miller, J. A. (2007). Synaphridae of Madagascar (Araneae: Araneoidea): A New Family Record for the Afrotropical Region. Proceedings of the California Academy of Sciences, 58(3), 21-48.

Miller, J. A., Carmichael, A., Ramírez, M. J., Spagna, J. C., Haddad, C. R., Rezáč, M., Johannesen, J., Král, J., Wang, X. P., \& Griswold, C. E. (2010). Phylogeny of entelegyne spiders: Affinities of the family Penestomidae (new rank), generic phylogeny of Eresidae, and asymmetric rates of change in spinning organ evolution (Araneae, Araneoidea, Entelegynae). Molecular Phylogenetics and Evolution, 55(3), 786-804.
Miller, J. A., Griswold, C. E., \& Yin, C. M. (2009). The symphytognathoid spiders of the Gaoligongshan, Yunnan, China (Araneae, Araneoidea): Systematics and diversity of micro-orbweavers. ZooKeys, 11, 9-195.

Millidge, A. F. (1984). The taxonomy of the Linyphiidae, based chiefly on the epigynal and tracheal characters (Araneae: Linyphiidae). Bulletin of the British Arachnological Society, 6(6), 229-267.

Millidge, A. F. (1986). A revision of the tracheal structures of the Linyphiidae (Araneae). Bulletin of the British Arachnological Society, 7, 57-61.

Müller, H.G. (1987) Spiders from Colombia V. A new Mysmenopsis from the Ciénaga Grande de Santa Marta, northern Colombia (Araneida: Mysmenidae). Bulletin of the British Arachnological Society 7, 185.

Nixon, K. (1999). WINCLADA, program and documentation. Available via www cladistics com.

Oakley, T. H., \& Cunningham, C. W. (2002). Molecular phylogenetic evidence for the independent evolutionary origin of an arthropod compound eye. PNAS, 99, 1426-1430.

Ono, H., Chang, Y. H., \& Tso, I. M. (2007). Three new spiders of the families Theridiidae and Anapidae (Araneae) from southern Taiwan. Memoirs of the National Science Museum Tokyo, 44, 71-82.

Ontano, A. Z., Gainett, G., Aharon, S., Ballesteros, J. A., Benavides, L. R., Corbett, K. F., Gavish-Regev, E., Harvey, M. S., Monsma, S., Santibáñez-López, C. E., Setton, E., Zehms, J. T., Zeh, J. A., Zeh, D. W., \& Sharma, P. P. (2021). Taxonomic sampling and rare genomic changes overcome long-branch attraction in the phylogenetic placement of pseudoscorpions. Molecular Biology and Evolution, 38(6), 2446-2467. https://doi.org/10.1093/ molbev/msab038

Opell, B. (1990). The relationship of book lung and tracheal systems in the spider family Uloboridae. Journal of Morphology, 206, 211-216.

Opell, B. (1998). The respiratory complementarity of spider book lung and tracheal systems. Journal of Morphology, 236, 57-64.

Peakall, D. B., \& Witt, P. N. (1976). The energy budget of an orb webbuilding spider. Comp. Biochem. Physiol. A, 54(1976), 187-190.

Petrunkevitch, A. (1933). An Inquiry into the natural classification of spiders, based on a study of their internal anatomy. Trans. Conn. Acad. Arts Sci., 31, 299-389.

Pickard-Cambridge, O. (1879). On some new and rare British spiders, with characters of a new genus. Annals and Magazine of Natural History, 5(4), 190-215.

Pickard-Cambridge, O. (1889). On some new species and a new genus of Araneida. Proceedings of the Zoological Society of London, 57(1), 34-46.

Pickard-Cambridge, O. (1894). Arachnida. Araneida. In: Biologia Centrali-Americana, Zoology. London 1, 121-144.

Platnick, N. I., \& Forster, R. R. (1986). On Teutoniella, an American genus of the spider family Micropholcommatidae (Araneae, Palpimanoidea). American Museum Novitates, 2854, 1-9.

Platnick, N. I., \& Forster, R. R. (1989). A revision of the temperate South American and Australasian spiders of the family Anapidae (Araneae, Araneoidea). Bulletin of the American Museum of Natural History, 190, 1-139.

Platnick, N. I., \& Forster, R. R. (1990). On the spider family Anapidae (Araneae, Araneoidea) in the United States. Journal of the New York Entomological Society, 98, 108-112.

Platnick, N. I., \& Shadab, M. U. (1978). A review of the spider genus Mysmenopsis (Araneae, Mysmenidae). American Museum Novitates, 2661, 1-22.

Platnick, N. I., \& Shadab, M. U. (1979). A review of the spider genera Anapisona and Pseudanapis (Araneae, Anapidae). American Museum Novitates, 2672, 1-20. 
Platnick, N.I. (1989). Advances in spider taxonomy 1981-1987: a supplement to Brignoli's A catalogue of the Araneae described between 1940 and 1981. Manchester University Press, 673 pp.

Prete, P. H., Cizauskas, I., \& Brescovit, A. D. (2018). Three new species of the spider genus Plato and the new genus Cuacuba from caves of the states of Pará and Minas Gerais, Brazil (Araneae, Theridiosomatidae). ZooKeys, 753, 107-162.

Purcell, W. F. (1909). Development and origin of respiratory organs in Araneae. Quart. J. Microsc. Sci., 54, 1-110.

Purcell, W. F. (1910). The phylogeny of trachea in Araneae. Quart. J. Microsc. Sci., 54, 519-563.

Quesada, R., Triana, E., Vargas, G., Douglass, J. K., Seid, M. A., Niven, J. E., Eberhard, W. G., \& Wcislo, W. T. (2011). The allometry of CNS size and consequences of miniaturization in orb-weaving and cleptoparasitic spiders. Arthropod Structure \& Development, 40(6), 521-529.

Ramírez, M. J., \& Platnick, N. I. (1999). On Sofanapis antillanca (Araneae, Anapidae) as a Kleptoparasite of Austrochiline Spiders (Araneae, Austrochilidae). The Journal of Arachnology, $27(2), 547-549$.

Ramírez, M. J. (2000). Respiratory system morphology and the phylogeny of haplogyne spiders (Araneae, Araneomorphae). Journal of Arachnology, 28, 149-157.

Ramírez, M. J. (2014). The morphology and phylogeny of dionychan spiders (Araneae: Araneomorphae). Bulletin of the American Museum of Natural History, 390, 1-394. https://doi.org/10. $1206 / 821.1$

Ramírez, M. J., Lopardo, L., \& Platnick, N. I. (2004). Notes on Chilean 1203 Anapids and their webs. American Museum Novitates, 3428, 1-13.

Ramírez, M. J., Magalhaes, I. L. F., Derkarabetian, S., Ledford, J., Griswold, C. E., Wood, H. M., \& Hedin, M. (2021). Sequencecapture phylogenomics of true spiders reveals convergent evolution of respiratory systems. Systematic Biology, 70, 14-20. https://doi.org/10.1093/sysbio/syaa043

Rix, M. G., \& Harvey, M. S. (2010). The spider family Micropholcommatidae (Arachnida, Araneae, Araneoidea): A relimitation and revision at the generic level. ZooKeys, 36, 1-321.

Rix, M. G. (2005). A review of the Tasmanian species of Pararchaeidae and Holarchaeidae (Arachnida, Araneae). Journal of Arachnology, 33, 135-152.

Rix, M. G., Harvey, M. S., \& Roberts, J. (2008). Molecular phylogenetics of the spider family Micropholcommatidae (Arachnida: Araneae) using nuclear rRNA genes (18S and 28S). Molecular Phylogenetics and Evolution, 46(3), 1031-1048.

Saaristo, M. I. (1978). Spiders (Arachnida, Araneae) from the Seychelle islands, with notes on taxonomy. Annales Zoologici Fennici, 15, 99-126.

Schmitz, A., \& Perry, S. (2000). Respiratory system of arachnids I: Morphology of the respiratory system of Salticus scenicus and Euophrys lanigera (Arachnida, Araneae, Salticidae). Arthropod Structure and Development, 29, 3-12.

Schmitz, A., \& Perry, S. (2001). Bimodal breathing in jumping spiders: Morphometric partitioning of the lungs and tracheae in Salticus scenicus (Arachnida, Araneae, Salticidae). Journal of Experimental Biology, 204, 4321-4334.

Schmitz, A., \& Perry, S. (2002). Respiratory organs in wolf spiders: Morphometric analysis of lungs and tracheae in Pardosa lugubris (L.) (Arachnida, Araneae, Lycosidae). Arthropod Structure and Development, 31, 217-230.

Schmitz, A. (2004). Metabolic rates during rest and activity in differently tracheated spiders (Arachnida, Araneae): Pardosa lugubris (Lycosidae) and Marpissa muscosa (Salticidae). Journal of Comparative Physiology B, 174, 519-526.

Schmitz, A. (2005). Spiders on a treadmill: Influence of running activity on metabolic rates in Pardosa lugubris (Araneae,
Lycosidae) and Marpissa muscosa (Araneae, Salticidae). Journal of Experimental Biology, 208, 1401-1411.

Schmitz, A. (2016). Respiration in spiders (Araneae). Journal of Comparative Physiology B, 186(4), 403-415.

Scholtz, G., \& Kamenz, C. (2006). The book lungs of Scorpiones and Tetrapulmonata (Chelicerata, Arachnida): Evidence for homology and a single terrestrialisation event of a common arachnid ancestor. Zoology, 109(1), 2-13.

Schütt, K. (2003). Phylogeny of Symphytognathidae s.l. (Araneae, Araneoidea). Zoologica Scripta, 32, 129-151.

Sharma, P. P., Kaluziak, S. T., Pérez-Porro, A. R., González, V. L., Hormiga, G., Wheeler, W. C., \& Giribet, G. (2014). Phylogenomic interrogation of Arachnida reveals systemic conflicts in phylogenetic signal. Molecular Biology and Evolution, 31, 2963-2984.

Simon, E. (1880). Matériaux pour servir à une faun arachnologique de la Nouvelle Calédonie. Annales de la Société Entomologique de Belgique 23(C.R.), 164-175.

Simon, E. (1881). Les arachnides de France. Tome cinquième, première partie. Roret, Paris, 1-180.

Simon, E. (1893). Études arachnologiques. 25e Mémoire. XL. Descriptions d'espèces et de genres nouveaux de l'ordre des Araneae. Annales De La Société Entomologique De France, 62, 299-330.

Simon, E. (1894). Histoire naturelle des araignées. Deuxième édition, tome premier. Roret, Paris, 489-760.

Simon, E. (1895a). Histoire naturelle des araignées. Deuxième édition, tome premier. Roret, Paris, 761-1084.

Simon, E. (1895b). Etudes arachnologiques. 26e. XLI. Descriptions d'espèces et de genres nouveaux de l'ordre des Araneae. Annales De La Société Entomologique De France, 64, 131-160.

Simon, E. (1898). On the spiders of the island of St Vincent. III. Proceedings of the Zoological Society of London 65(4, for 1897), 860-890.

Simon, E. (1899). Contribution à la faune de Sumatra. Arachnides recueillis par M. J. L. Weyers, à Sumatra. (Deuxiéme mémoire). Annales De La Société Entomologique De Belgique, 43, 78-125.

Simon, E. (1905). Arachnides de Java, recueillis par le Prof. K. Kraepelin en 1904. Mitteilungen Aus Dem Naturhistorischen Museum in Hamburg, 22, 49-73.

Simon, E. (1922). Description de deux arachnides cavernicoles du midi de la France. Bulletin De La Société Entomologique De France, 1922, 199-200.

Snazell, R. (2009). An unusual new anapid spider from the rainforest of Brunei (Araneae: Anapidae). Bulletin of the British Arachnological Society, 14, 371-373.

Song, D.X., Zhu, M.S. \& Chen, J. (1999). The spiders of China. Hebei University of Science and Techology Publishing House Shijiazhuang, $640 \mathrm{pp}$.

Sundevall, C.J. (1833). Conspectus Arachnidum. Londini Gothorum, $1-39$.

Thaler, K. (1995). Mysmeniola spinifera n.gen. n.sp., eine merkwürdige Kleinspinne aus Venezuela (Arachnida, Araneae: Mysmenidae). Mitteilungen der Schweizerischen Entomologischen Gesellschaft 68(3-4), 429-433.

Vollrath, F. (1978). A close relationship between two spiders (Arachnida, Araneidae): Curimagua bayano synecious on a Diplura species. Psyche (Camb., Mass.) 85, 347-353.

Wheeler, W. C., Coddington, J. A., Crowley, L. M., Dimitrov, D., Goloboff, P. A., Griswold, C. E., Hormiga, G., Prendini, L., Ramírez, M. J., Sierwald, P., Almeida-Silva, L. M., Álvarez-Padilla, F., Arnedo, M. A., Benavides, L. R., Benjamin, S. P., Bond, J. E., Grismado, C. J., Hasan, E., Hedin, M., ... Zhang, J. X. (2017). The spider tree of life: Phylogeny of Araneae based on target-gene analyses from an extensive taxon sampling. Cladistics, 33(6), 576-616. https://doi. org/10.1111/cla.12182 
Wirkner, C. S., Tögel, M., \& Pass, G. (2013). The Arthropod Circulatory System. In A. Minelli, G. Boxshall, \& G. Fusco (Eds.), Arthropod biology and evolution - Molecules, development, morphology (pp. 343-391). Springer.

World Spider Catalog. (2020). World Spider Catalog. Version 21.5. Natural History Museum Bern, online at http://wsc.nmbe.ch. Accessed on 28 December 2020. doi: 10.24436/2.

Wunderlich, J., \& Song, D. X. (1995). Four new spider species of the families Anapidae, Linyphiidae and Nesticidae from a tropical rain forest area of SW-China. Beiträge Zur Araneologie, 4(1994), 343-351.
Wunderlich, J. (1995). Drei bisher unbekannte Arten und Gattungen der Familie Anapidae (s.l.) aus Süd-Afrika, Brasilien und Malaysia (Arachnida: Araneae). Beiträge zur Araneologie 4(1994), 543-551.

Publisher's Note Springer Nature remains neutral with regard to jurisdictional claims in published maps and institutional affiliations. 